IHS Working Paper 9

November 2019

\title{
Public Charging Infrastructure and the Market Diffusion of Electric Vehicles
}

Ulrike IIImann Jan Kluge 


\section{Author(s)}

Ulrike Illmann, Jan Kluge

\section{Editor(s)}

Robert M. Kunst

Title

Public Charging Infrastructure and the Market Diffusion of Electric Vehicles

Institut für Höhere Studien - Institute for Advanced Studies (IHS)

Josefstädter Straße 39, A-1080 Wien

$\mathrm{T}+431$ 59991-0

$\mathrm{F}+43159991-555$

www.ihs.ac.at

ZVR: 066207973

\section{License}

„Public Charging Infrastructure and the Market Diffusion of Electric Vehicles" by Ulrike Illmann, Jan Kluge is licensed under the Creative Commons: Attribution 4.0 License (http://creativecommons.org/licenses/by/4.0/)

All contents are without guarantee. Any liability of the contributors of the IHS from the content of this work is excluded.

\section{IRIHSS}

All IHS Working Papers are available online:

https://irihs.ihs.ac.at/view/ihs_series/ser=5Fihswps.html

This paper is available for download without charge at: https://irihs.ihs.ac.at/id/eprint/5197/ 


\title{
Public Charging Infrastructure and the Market Diffusion of Electric Vehicles
}

\author{
Ulrike Illmann * Jan Kluge ${ }^{\dagger}$
}

November 7, 2019

\begin{abstract}
A comprehensive roll-out of public charging infrastructure will be costly. However, its impact on the diffusion of electric vehicles (EVs) is not clear at all. Our study aims at estimating the extent to which an increasing availability of public charging infrastructure promotes consumers' decisions to switch to EVs. We make use of a German data set including monthly registrations of new cars at the ZIP-code level between 2012 and 2017 and match it with the official registry of charging stations. We measure charging infrastructure by its visibility, capacity and abundance in order to estimate its impact on EV adoption. A CS-ARDL approach is deployed in order to identify the structural long-run relationship between charging infrastructure and monthly EV registrations. There is evidence of a positive long-run relationship but on a rather low scale. We conclude that consumers do not necessarily react to the mere number of chargers but attach more importance to charging speed.
\end{abstract}

Keywords: Electric vehicles, charging infrastructure, CS-ARDL

JEL classification: L90, O18, O33, R42

* Ulrike Illmann, TU Dresden, Germany, ulrike.illmann@tu-dresden.de

$\dagger$ Jan Kluge, Institute for Advanced Studies (IHS), Vienna, Austria, kluge@ihs.ac.at 


\section{Motivation and background}

In this paper we investigate the relationship between the regional availability of public charging infrastructure and the diffusion of electric vehicles $(\mathrm{EVs})$ in private households.

The emissions produced in the transport sector are currently responsible for a quarter of Europe's overall greenhouse gas (GHG) emissions (see European Environment Agency, 2016). Not only do they contribute to global warming, they also result in high local concentrations of air pollution that might lead to long-term effects such as health issues (see, e. g., Brady and O'Mahony, 2011; Requia et al., 2018). According to the German Environment Agency (2017), the transport sector alone induced almost $19 \%$ of the GHG emissions in Germany in 2017. Around half of the road transport is produced by car passenger transport; the EU Commission (2018) even recorded an increasing use of passenger cars in Germany compared to the EU-28 average. Hence, an increase of eco-friendly passenger cars can be expected to significantly lower emissions, especially in densely populated areas.

Accordingly, the EU is eager to make the transport sector more sustainable, in particular by pushing electric vehicles into the center of the consumers' attention. All types of EVs have the potential to lower GHG emissions as they come with higher energy efficiency scores than conventional cars with combustion engines (see, e. g., European Environment Agency, 2016); the energy mix will also play an important role (see, e. g., Cavallaro et al., 2018). Two types of electric car technologies are particularly interesting for our study: Battery electric vehicles (BEV) and plug-in hybrid electric vehicles (PHEV); the latter have a chargeable battery but also a traditional combustion engine. ${ }^{1}$

Most cars in the EU, however, are still powered by gasoline or diesel engines; only a small proportion of the fleet is already electric. The sales of BEVs and PHEVs are increasing, but they made up only $1.4 \%$ of new car sales in the EU in 2017 (ICCT, 2018); ${ }^{2}$ the share in Germany was 1.6 \% (Federal Motor Transport Authority, 2019). The pioneers regarding EV adoption are well ahead of the EU: For instance, one-third of new cars sold in Norway in 2017 were electric (European Environment Agency, 2018).

In order to understand how EV adoption can be further promoted, researchers are interested in finding potential barriers that hinder consumers purchasing EVs. A lack of

\footnotetext{
${ }^{1}$ Other types of electric cars without external charging possibility (e. g. the popular hybrid electric vehicles (HEV) with batteries charged through brake energy) are not relevant for our study as they do not require charging infrastructure.

${ }^{2}$ HEVs made up about $2.7 \%$.
} 
public charging infrastructure ${ }^{3}$ could be one of them (see, e. g., Hardman et al., 2018; Kihm and Trommer, 2014; Sierzchula et al., 2014). If charging infrastructure is not sufficiently provided within reasonable driving distances, even consumers who are generally interested in buying an EV are fearing discharged batteries during trips with no charging station in sight (see, e. g., Franke and Krems, 2013). This so-called range anxiety decreases EV adoption but could be avoided by building up public charging infrastructure so that consumers can always reach a nearby charger.

Currently, the amount of charging infrastructure is relatively small, and the use of already existing chargers often comes with challenges for consumers as the operating modes differ: There are different plug-types that do not fit every vehicle, different registration modes (e. g. membership cards to access or phone identification) and pricing models (consumers can be charged by kilowatt-hour (kWh), by hours parked at the station or by the actual charging time (see, e. g., Hardman et al., 2018)).

Even though charging systems differ, many governments within or outside the EU emphasize implementing charging infrastructure as one way to push more EV registrations. Apart from financial incentives (see, e. g., Gallagher and Muehlegger, 2011; Hardman et al., 2017; Tscharaktschiew, 2015), non-financial incentives (e. g. allowance to use bus lanes) and raising awareness, governments argue how and where to invest in public charging infrastructure (see, e. g., Gass et al., 2014; Sierzchula et al., 2014). The German Government (2018) states in its coalition agreement that at least 100,000 charging stations should be available by the year 2020. The EU Parliament (2018, p. 4) passed a directive that reads: "As an indication, the appropriate average number of recharging points should be equivalent to at least one recharging point per 10 cars."

Public charging infrastructure might indeed be crucial for EV diffusion, but it is only one out of three ways how to charge an EV. One of the great advantages of EVs is the possibility to charge them at home or work. These two charging options cover most of the daily charging needs of potential consumers. ${ }^{5}$ Franke and Krems (2013), for instance, postulate that most charging in Germany will occur at home. Nevertheless, they conclude that public charging stations are essential for EV consumers. Especially for their stated

\footnotetext{
3 "Public" means that the respective charging station can be accessed and used by everyone. Hence, it is even considered public when it is operated by private institutions or individuals, when located on private property, or when charging might require registration and payment.

${ }^{4}$ Public charging can even be free, e. g. at supermarkets that install chargers in their parking lots for image reasons and to provide convenience effects for their customers.

${ }^{5}$ However, Fetene et al. (2016) show that charging at work is not economically reasonable both for firms and workers. It is thus not expected to gain major importance.
} 
driving range preferences and if no private charging station is available during trips. Hence, public chargers complement the general need for charging facilities, even though many EV owners will hardly ever use them.

In Norway, where EV adoption is most developed, $75 \%$ of EV users have private charging (see Figenbaum, 2017); if they travel longer distances they switch to conventional cars to avoid the limited driving distances of EVs (see Figenbaum and Kolbenstvedt, 2016). Nonetheless, there is a need for public infrastructure, especially in areas where home chargers can not be installed, e. g., in dense areas with multi-family homes. An experiment by Nicholas et al. (2017) in the U.S. shows that many EV users charge closer to their homes (within $\approx 14$ miles $(\approx 22 \mathrm{~km})$ ) than models of optimal charging locations would predict. The distances decrease even further when free charging is provided (to $\approx 5$ miles $(\approx 8 \mathrm{~km}))$.

Further, it is worth mentioning that the different types of EVs come with different charging requirements: PHEV owners are interested in using the more efficient electric mode as often as possible, but they still have a combustion engine as a fallback option. BEV consumers, however, depend on sufficient charging infrastructure, especially when being far from home. Hence, the charging infrastructure effect on EV registrations - if it exists - might differ between BEVs and PHEVs.

As local public charging infrastructure is considered necessary to push EV adoption, we ask about the actual impact of charging infrastructure on EV adoption of private households. The remainder of this paper is organized as follows: Section 2 presents the previous literature on the matter. Section 3 presents our data on EV registrations and charging infrastructure before Section 4 outlines the methodological approach. The empirical results are presented and interpreted in Section 5. Section 6 concludes.

\section{Literature}

In the last years, different research strands developed approaches to investigate the adoption process of EVs. Besides discrete choice analysis of EV preferences, there are also market share analyses, (spatial) econometric models of EV adoption and market diffusion modeling in order to examine the electrification of individual passenger transport. Our research 
adds to the first three mentioned fields. ${ }^{6}$ In what follows, we briefly provide an overview of the current state of research and its results.

There is a substantial body of empirical research concerning EV adoption on an individual level. Since we are interested in the EV adoption of private households, we review literature that investigates the purchase decision process of individuals. Most studies perform choice experiments to learn about individual preferences and provide insights into various vehicle ownership decisions and willingness to pay for electric mobility. Rezvani et al. (2015) summarize EV adoption behaviors such as consumers' personal beliefs, personalities, perceptions, or emotions. Further, it can generally be concluded that EV ownership is highly influenced by socio-demographics. Those individuals are interested in EVs who are middle-aged (see, e. g., Musti and Kockelman, 2011), male (see, e. g., Rasouli and Timmermans, 2016), who obtained higher educational levels (see, e. g., Hackbarth and Madlener, 2013), work full-time (see, e. g., Plötz et al., 2014) and earn middle to high incomes (see, e. g., Musti and Kockelman, 2011). ${ }^{7}$

EV consumers also show preferences concerning the existing charging infrastructure. They often relate to its availability and express their range anxiety. It is noticeable that authors use different measures of infrastructure availability: Some studies use distances between charging infrastructure and consumers' residence locations (see, e. g., Rasouli and Timmermans, 2016) while others use the existence, density or percentage of charging infrastructure in certain areas (see, e. g., Hackbarth and Madlener, 2013; Javid and Nejat, 2017). Hackbarth and Madlener (2013) show in a web-based survey that potential consumers are willing to pay more for an EV if driving ranges and charging infrastructure availability improve. Hidrue et al. (2011) find that consumers are willing to pay about $\$ 35$ to $\$ 75$ in order to increase their car's driving range by one additional mile. Axsen and Kurani (2013) reveal in their experiment that respondents would not select EVs due to missing charging options near their home. In a further investigation, Axsen et al. (2017) consider how main-streamers differ from early adopters in their knowledge of the charging process. It turns out that most interviewees had only little knowledge of energy sources and charge modes. Even though handling and functionality may still be tricky, most studies conclude that the impact of public infrastructure on EV adoption is positive; hence, charging infrastructure is needed for EV diffusion (see, e. g., Javid and Nejat, 2017; Potoglou and Kanaroglou, 2007; Sierzchula et al., 2014). Liao et al. (2017) argue

\footnotetext{
${ }^{6}$ For further reading on market diffusion models (for instance with the help of CGE models) see, e. g., Gnann and Plötz (2015) for an overview or Schmelzer and Miess (2015) for a cost-benefit analysis.

${ }^{7}$ For an overview of EV user characteristics see, e. g., Liao et al. (2017) or Coffman et al. (2017).
} 
that increased infrastructure availability eases range anxiety and reduces search costs for charging points.

The studies mentioned above rely on stated preferences since EVs have only recently been introduced to the broad public. Stated preferences can be useful in order to study even hypothetical EV purchases (see, e. g., Hensher, 2010). Research with extensive revealed preference data, on the other hand, is relatively limited. However, Axsen et al. (2009) state that revealed preferences show more accurate estimates when it comes to EV adoption as there is a gap between the environmentally friendly attitudes of consumers and their actual behavior. Lane and Potter (2007) also show that consumers differ severely between their attitudes towards the new technology and their actual purchase, especially when it comes to eco-friendly mobility.

Most studies with revealed preferences use linear regression analyses to describe influencing factors on EV adoption. Neaimeh et al. (2017) examine the correlation between daily driving distances and standard $(22 \mathrm{~kW})$ and fast $(\geq 50 \mathrm{~kW})$ public charge events by using OLS and robust regression models. Results show that fast chargers are more influential than standard ones if the daily travel distances are above $240 \mathrm{~km}$. For short daily travel distances, standard chargers are sufficient. Sierzchula et al. (2014) investigate EV adoption factors, such as incentives, fuel prices, and charging infrastructure in 30 different countries conducting correlation analysis and OLS regressions in order to understand their impact on EV market shares. The development of country-specific charging infrastructure is one of the most significant impacts according to their results. ${ }^{8}$ Bailey et al. (2015) are interested in whether the consumers' awareness of public chargers increases EV adoption. By conducting a cross-sectional regression analysis, they conclude that public chargers alone provide only little explanation. However, the statistical correlation increases if potential consumers are aware of multiple charging locations.

Adjemian et al. (2010) argue that there is also a spatial component to EV adoption. Failure to account for spatial structures might lead to efficiency losses in the estimation. They show that residents are more likely to choose a new EV that is also favored by their neighbors. Liu et al. (2017) reach the same conclusion that geographical neighbors positively affect EV purchases by conducting spatial econometric models for Ohio, USA. Axsen and Kurani (2011) focus on the spatial impacts of social networks and also conclude that such peer effects exist. Bansal et al. (2015), Chen et al. (2015) and Dimatulac and Maoh (2017) conduct spatial count models in the U.S. and Canada on tract-levels. They

\footnotetext{
8 Although they do not claim to provide evidence for a causal relationship.
} 
investigate socio-demographic spatial patterns in EV choice behavior and find evidence that adoption is locally clustered, especially in central areas. However, they do not consider the impact of spatially distributed chargers in the region.

Our contribution to the existing research is threefold. First, we make use of unique revealed preference data of private households over a longer time span to examine the evolution of EV adoption and shed light on potential influencing factors in terms of charging infrastructure. We use data on monthly EV registrations at the German ZIP-code level from 2012 to 2017.

Second, with the available data, we are able to explore the short-run dynamics and structural long-run effects of local charging infrastructure on EV adoption, accounting for non-stationarity issues, possible heterogeneity between regions, and for potential cross-sectional dependence due to common shocks or spatial spillover effects.

Finally, we distinguish between different measures of local charging infrastructure (the effects of visibility, capacity and abundance of local chargers) to understand the mechanisms through which charging infrastructure influences private EV adoption.

\section{Data}

\subsection{Electric Vehicles}

Our revealed preference data on EVs has been provided by the German Federal Motor Transport Authority (2018). It covers monthly registrations of electric and conventional passenger vehicles for private use up to 3.5 tons at the ZIP-Code level. As the data set starts in 2009, it includes almost every EV ever registered by German households. All types of EVs are recorded within one group until 2011. As PHEVs started to become popular around this time, the data set distinguishes PHEVs and BEVs from 2012 onward. As the rationale to purchase one of the two types of cars and the role played by charging infrastructure might differ (see Section 1), we will provide separate estimates for overall EV but also PHEV and BEV registrations. To put the monthly registrations into perspective, we simply use EVs, PHEVs, and BEVs per 1,000 overall car registrations in a region as our dependent variables. Cars registered with businesses are excluded as their purchasing rationales must not be compared to private households. 


\subsection{Charging Infrastructure}

Our data on charging infrastructure stem from the German Federal Network Agency (2019) that keeps track of every public charging facility in Germany. This official register includes detailed information on the respective location, implementation date, technical parameters (e. g. charging capacity or plug types), as well as the name of the operator. ${ }^{9}$

The studies mentioned in Section 2 show different investigation strategies and different definitions of charging infrastructure. Nevertheless, they reveal that the number of public charging points and the available charging capacities might be relevant for the EV purchase decisions of households. In the following, we present how we measure public charging infrastructure. ${ }^{10}$

First, the mere appearance of public chargers might have an effect on EV adoption. As charging stations often have an exclusive location (e. g. in parking lots right in front of the entrance or close to the road nearby), we hypothesize that it attracts the attention of prospective EV users, even before knowing the details of charging capacities, plug types, etc. We will refer to this as visibility effect.

Though not visible from a distance, the charging capacity might be at least as important as the mere number of charging points as it determines the waiting time before a car journey can be continued. Yang et al. (2016) show that potential EV consumers are significantly driven by the location of a charging station as well as by the charging time. Consumers often expect the charging process to be no longer than refueling a conventional car (see, e. g., Gnann et al., 2018). However, a standard charger (22 kW) needs almost two and a half hours to fully recharge a typical EV battery with a capacity of $40 \mathrm{kWh}$ when the car gets plugged in with a remaining charge level of $20 \%$. A fast charger with $50 \mathrm{~kW}$ would only take about one hour. Most public charging stations, however, are so-called level-2 chargers with capacities around $22 \mathrm{~kW}$. Morrissey et al. (2016) and Figenbaum and Kolbenstvedt (2016) show that fast chargers are used more often than others, especially at car parks and parking garages. ${ }^{11}$ Hence, our second measure for charging infrastructure is the overall capacity within a region. We refer to this as the capacity effect.

Besides the visibility and capacity of charging stations, studies have observed uncontrolled

\footnotetext{
${ }^{9}$ Since March 17, 2016 providers are obligated to report public chargers to the Federal Network Agency (see $\S 5(1)$ and (4) LSV).

10 We drop charging stations with capacities of less than $11 \mathrm{~kW}$. Usually, only home chargers come with such low capacities. They are not suitable for public charging as dwell times would be very long.

11 Figenbaum and Kolbenstvedt (2016) conducted a survey on Norwegian EV owners and state that around $8 \%$ use fast chargers once a week ( $28 \%$ once a month).
} 
charging during peak hours. Gnann et al. (2018), for instance, report a peak demand around 3 pm in Norway and Sweden; Figenbaum and Kolbenstvedt (2016) report peaks around 4 to 6 pm. ${ }^{12}$ Most chargers are occupied during such peak times. Fast charging is now of the essence as it reduces waiting times and increases the throughput of cars. Hence, not only visibility and overall regional capacity will do the trick, but the average charging speed of the stations available. Ten $50 \mathrm{~kW}$ stations might be more effective for EV adoption than twenty-five $20 \mathrm{~kW}$ stations, even though the capacity measure is the same and the visibility measure is even lower in this example. Hence, we include the average charging capacity per station as our third infrastructure measure and call it abundance effect. It captures the fact that fast chargers are more often available (or will become available more quickly if occupied).

We will make use of all three measures of charging infrastructure - visibility, capacity and abundance - in order to estimate its impact on EV adoption. We will, however, use them one by one in our estimation specifications as there might be some overlap between what the three variables measure.

\subsection{Descriptive statistics}

We aggregate our data to the 3 -digit ZIP-Code level ${ }^{13}$ and drop regions that have not experienced at least one EV registration and one charging station installation by the end of 2017 (usually large forests or otherwise uninhabited areas). In order to be able to distinguish between BEVs and PHEVs, we drop the first three years of our observation period (as PHEVs were not recorded between 2009 and 2011); this comes with a loss of only $2.2 \%$ of EV registrations. In doing so, we yield a strongly balanced panel data set with 594 groups and a time dimension of 72 months (01/2012 - 12/2017).

Table 1 shows some descriptive statistics. Not surprisingly, the variables have increased massively within the 6-year period between January 2012 and December 2017 but, nonetheless, remain at a rather low level. Table 1 shows that an average 3 -digit ZIP-Code contained about 16 public charging stations and experienced about $26 \mathrm{EV}$ registrations $(15 \mathrm{BEVs}$ and 11 PHEVs) per 1,000 registrations in December 2017. The average charging capacity was $24 \mathrm{~kW}$ per station; the average overall charging capacity was $354 \mathrm{~kW}$.

\footnotetext{
12 See also Azadfar et al. (2015) for an overview of EV charging behavior.

13 An average 3-digit ZIP-Code is much smaller than an average district (NUTS-3) and, thereby, captures an area within which every point is in reasonable driving distance.
} 
Table 1

Descriptive statistics

\begin{tabular}{|c|c|c|c|c|}
\hline \multicolumn{5}{|c|}{ January 2012} \\
\hline & Mean & Std. Dev. & Min. & $\operatorname{Max}$. \\
\hline Electric vehicles (EVs) & 0.82 & 2.97 & 0 & 39.17 \\
\hline battery only (BEVs) & 0.82 & 2.97 & 0 & 39.17 \\
\hline plug-in hybrid (PHEVs) & 0.00 & 0.00 & 0 & 0 \\
\hline $\begin{array}{l}\text { Number of charging stations } \\
\quad(=\text { visibility effect })\end{array}$ & 1.40 & 4.34 & 0 & 56 \\
\hline $\begin{array}{l}\text { Overall charging capacity (in } \mathrm{kW}) \\
\quad(=\text { capacity effect })\end{array}$ & 28.51 & 90.80 & 0 & 1,232 \\
\hline $\begin{array}{l}\varnothing \text { charging capacity (in } \mathrm{kW} / \text { station) } \\
\quad(=\text { abundance effect })\end{array}$ & 5.47 & 9.49 & 0 & 50 \\
\hline \multicolumn{5}{|c|}{ December 2017} \\
\hline & Mean & Std. Dev. & Min. & Max. \\
\hline Electric vehicles (EVs) & 25.91 & 23.53 & 0 & 283.95 \\
\hline battery only (BEVs) & 14.90 & 20.77 & 0 & 283.95 \\
\hline plug-in hybrid (PHEVs) & 11.01 & 9.22 & 0 & 73.17 \\
\hline $\begin{array}{l}\text { Number of charging stations } \\
(=\text { visibility effect })\end{array}$ & 16.04 & 16.57 & 1 & 137 \\
\hline $\begin{array}{l}\text { Overall charging capacity (in } \mathrm{kW}) \\
\quad(=\text { capacity effect })\end{array}$ & 353.66 & 341.24 & 11 & 2,174 \\
\hline $\begin{array}{l}\varnothing \text { charging capacity (in kW/station) } \\
\quad(=\text { abundance effect })\end{array}$ & 23.90 & 14.12 & 5.5 & 162.5 \\
\hline Overall obs: $42,768-$ Groups (3-dig & ZIP C & $4-$ Poir & 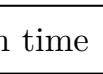 & $: 72$ \\
\hline
\end{tabular}

Source: Federal Network Agency (2019), Federal Motor Transport Authority (2018).

Figure 1 maps the accumulated EV registrations (in absolute terms; Figure 1a), the spatial distribution of charging stations (Figure 1b), the overall charging capacity (in kW, Figure 1c) and the average charging capacity (in kW per charging point, Figure 1d) as of December 2017. Obviously, EVs are more popular in urban areas towards western Germany. A certain nexus between EVs and charging infrastructure is already visible; however, the maps also reveal some regions with considerable numbers of EV registrations but with virtually no public charging infrastructure at all. This is possible in rural areas where most households can have private charging facilities.

All in all, the four variables show steep upward trends over time, as indicated by Figure 2. The widening gap between overall charging capacity and the number of charging stations in recent years shows that fast charging is gaining importance. 


\section{Figure 1}

Charging infrastructure and electric vehicles (EVs) in Germany as of December 2017

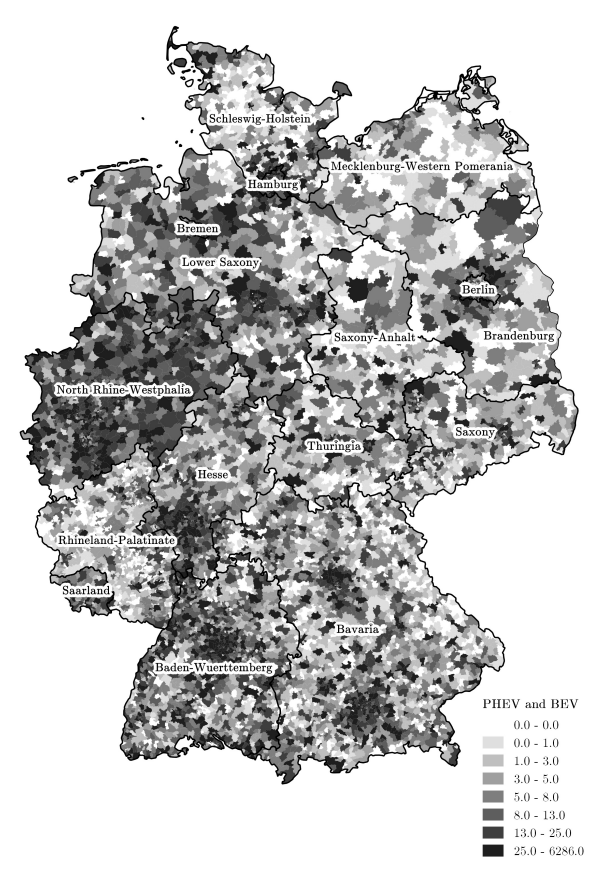

(a) Electric vehicles (EVs)

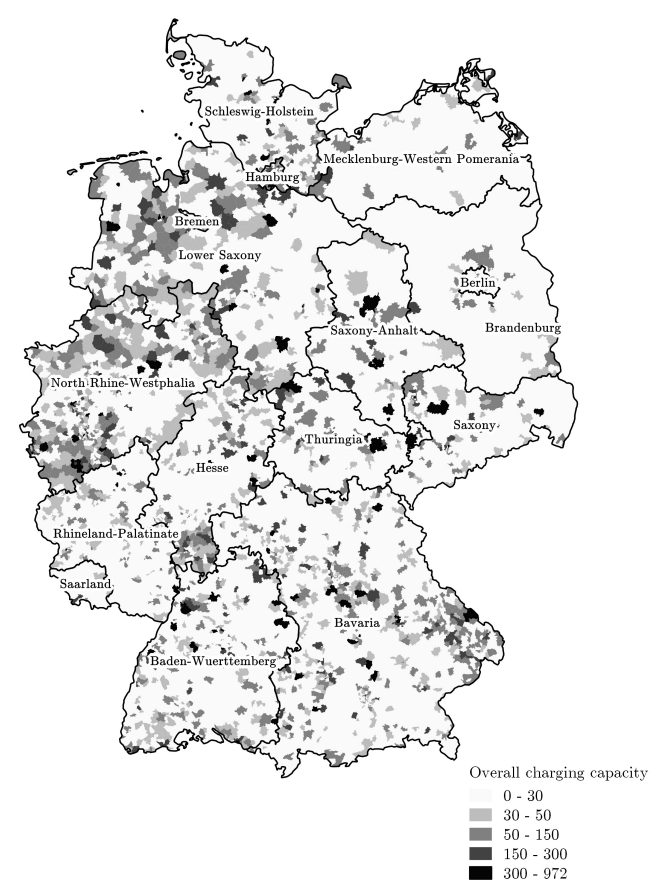

(c) Overall charging capacity $(k W)$

- capacity effect -

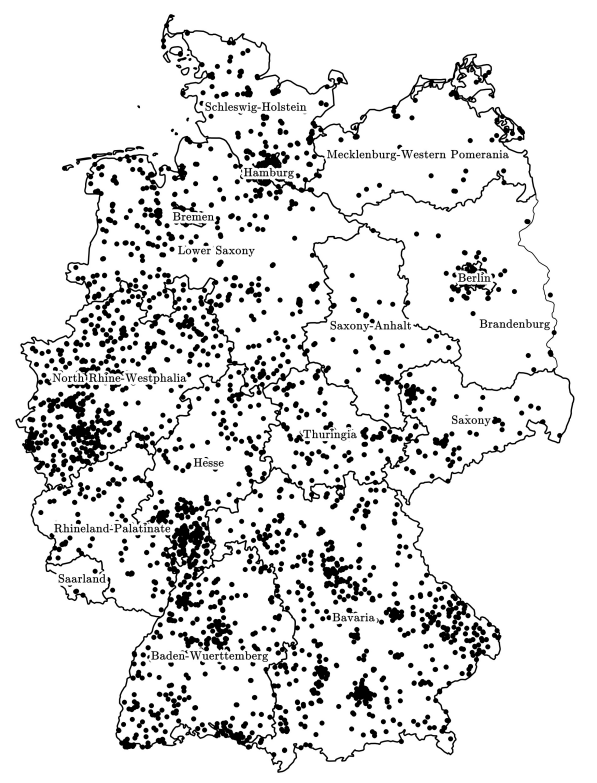

(b) Number of charging stations - visibility effect -

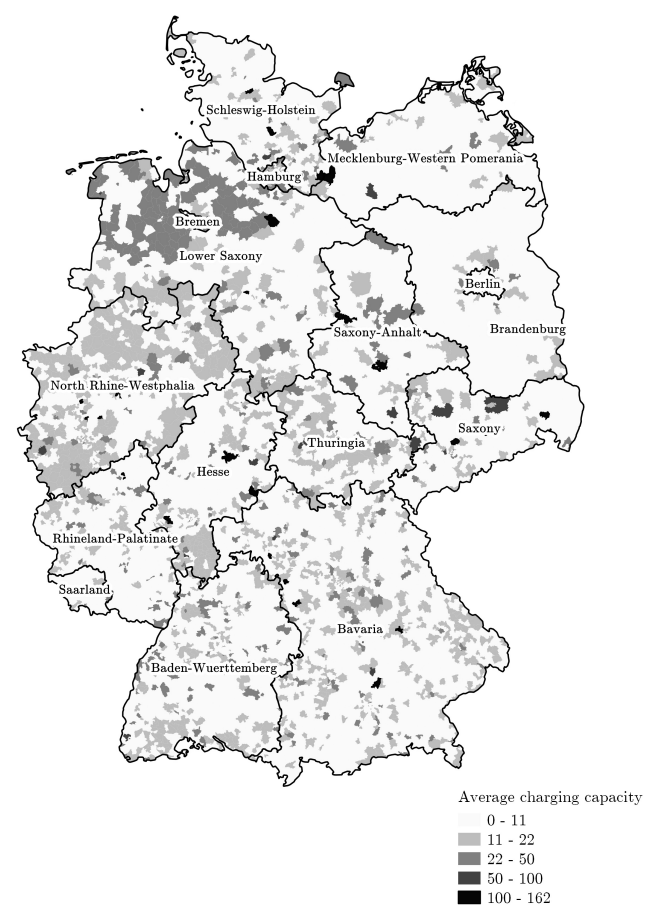

(d) Average charging capacity

( $\mathrm{kW} /$ charging station)

- abundance effect -

Source: Federal Network Agency (2019), Federal Motor Transport Authority (2018). 


\section{Figure 2}

Electric vehicle (EV) registrations and charging infrastructure in Germany

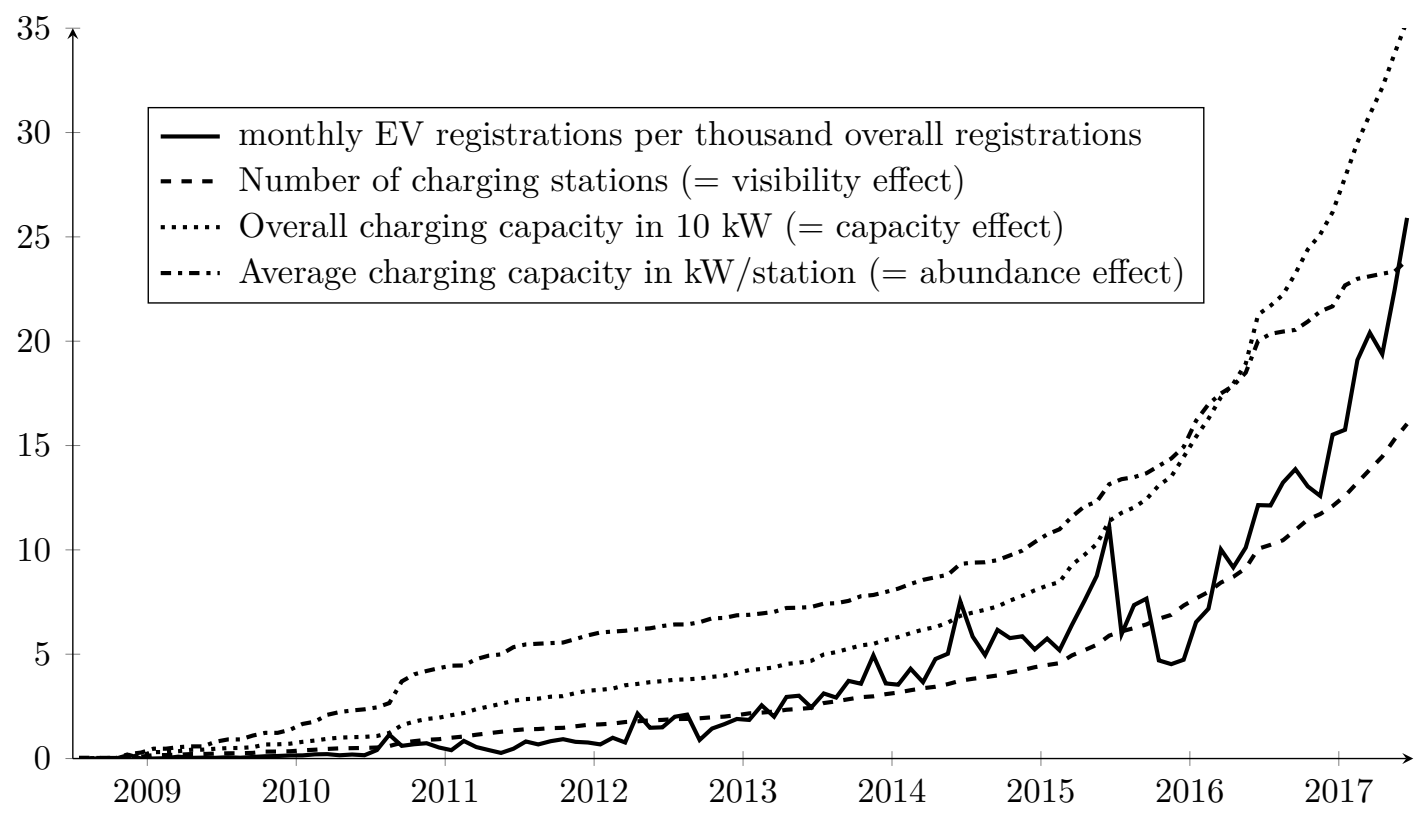

Source: Federal Network Agency (2019), Federal Motor Transport Authority (2018)

\section{Estimation approach and econometric issues}

We aim at estimating the short- and long-run relationship between charging infrastructure and EV registrations. Our data set comes with a variety of challenges that call for a thoughtful econometric setup. The following section 4.1 presents our estimation approach. In the subsequent section 4.2, we describe the econometric issues inherent to the data and sketch how to tackle them.

\subsection{Estimation approach}

In order to estimate the relationship between EV registrations and charging infrastructure we consider a cross-sectional augmented autoregressive distributed lag (CS-ARDL) model as proposed by Chudik and Pesaran (2015) and shown in Equation 1:

$$
E V_{i, t}=c_{i}+\sum_{j=1}^{p_{E V}} \gamma_{i, j} E V_{i, t-j}+\sum_{j=0}^{p_{\mathbf{C}}} \delta_{i, j} C_{i, t-j}+\lambda_{i}^{\prime} \mathbf{f}_{t}+\epsilon_{i, t}
$$

where $E V_{i, t}$ captures registrations of electric vehicles per 1,000 registrations in region $i$ 
at time $t^{14}$. $C_{i, t}$ captures the respective measure of charging infrastructure in region $i$ at time $t$ indexed by $j$. The parameter vector $\lambda_{i}^{\prime}$ captures the effects by a set of unobserved common factors $\mathbf{f}_{t}$ that the $\mathrm{EV}$ registrations in all regions might be subject to. According to Chudik and Pesaran (2015), $\mathbf{f}_{t}$ can be proxied by cross-sectional means of $E V_{i, t}$ and $C_{i, t}$ and a sufficient number of lags thereof. Hence:

$$
\lambda_{i}^{\prime} \mathbf{f}_{t} \equiv \sum_{j=0}^{p_{\overline{\mathbf{Z}}}} \lambda_{i, j}^{\prime} \overline{\mathbf{Z}}_{t-j}
$$

with $\overline{\mathbf{Z}}_{t}=\left(\overline{E V}_{t}, \bar{C}_{t}\right)$. Plugging (2) in (1) and rearranging the equation gives a standard error-correction model:

$$
\begin{aligned}
\Delta E V_{i, t} & =\sum_{j=1}^{p_{E V}} \gamma_{i, j} \Delta E V_{i, t-j}+\sum_{j=0}^{p_{C}} \delta_{i, j} \Delta C_{i, t-j}+\sum_{j=0}^{p_{\overline{\mathbf{Z}}}} \lambda_{i, j}^{\prime} \overline{\mathbf{Z}}_{t-j} \\
& +\phi_{i}\left(E V_{i, t-1}-\hat{\beta}_{0}-\hat{\beta}_{1} C_{i, t}\right)+\epsilon_{i, t}
\end{aligned}
$$

We are particularly interested in the parameter $\hat{\beta}_{1}$ as it represents the long-run relationship between EVs and charging infrastructure. It is estimated using a standard OLS regression. If the respective error term follows an $\mathrm{I}(0)$ distribution, the term in parentheses will represent an equilibrium relationship between $E V$ and $C$. This will be the case even if $E V$ and $C$ are non-stationary. Pesaran et al. (1999) show that ARDL estimation is consistent as long as the variables are $\mathrm{I}(0)$ or $\mathrm{I}(1)$. The error correction parameter $\phi_{i}$ will then determine the rate at which disturbances from this equilibrium will be corrected for. The parameters $\delta_{i, j}$ represent the short-run dynamics between $E V$ and $C, \gamma_{i, j}$ capture the effect of the autoregressive term and $\epsilon_{i, t}$ is the error term. The parameter vector $\lambda_{i, j}$ depicts the coefficients of the cross-sectional averages that proxy our unobserved common factors.

The CS-ARDL model, as proposed by Chudik and Pesaran (2015), is capable of estimating long-run effects in dynamic, heterogeneous panels and thereby solves issues that panel data usually comes with. It has been extensively used, e. g. for the analysis of economic growth (see, e. g., Chudik et al., 2017) or government aid (see, e. g., Herzer, 2019). In the following section, we look closer at the characteristics of our data set and explain why CS-ARDL is the appropriate method to analyze our research question.

${ }^{14}$ In the remainder of the analysis, the variable $E V_{i, t}$ is defined with registrations of $\mathrm{BEV}, \mathrm{PHEV}$ or $\mathrm{EV}$ per 1,000 registrations in region $i$ at time $t$. 


\subsection{Econometric issues}

\subsubsection{Non-stationarity}

The first and most severe problem in our data set is certainly non-stationarity: We observe the development of EVs in Germany from its very beginning, i. e. from 2009 when almost no EV was registered till 2017 when thousands of EVs were recorded. Hence, it would not come as a surprise if the development of EV registrations and charging infrastructure was non-stationary. Figure 2 in the last section already produced that conjecture.

Unit root testing in panels is always troubling as the available tests differ in terms of hypotheses and assumptions and, therefore, often lead to contradicting results. Commonly used tests formulating the null hypothesis that all panels are non-stationary with the same autoregressive parameter (as proposed, i. a., by Levin et al., 2002) might be as hard to justify in large heterogeneous panels as their alternatives with null hypotheses of all panels being stationary (as proposed, i. a., by Hadri, 2000). Pesaran (2012) states that the discussion about how to construct panel unit root tests can be easily avoided when $T$ is large enough to perform individual tests and then focus on the respective proportions of stationary and non-stationary series.

We follow this recommendation and augment a standard heteroskedasticity-robust unit root test (Hadri, 2000) with the information about the fractions of non-stationary/stationary series in our sample. Table 2 shows the results.

As expected, we find that all variables must be considered non-stationary in levels (indicated by .); this is true for the majority of series in the sample. The first differences (indicated by $\Delta$ ), however, are stationary, at least for the EV variables and for the abundance measure of charging infrastructure. Even though the Hadri (2000) test would still indicate non-stationarity for the two other infrastructure measures, this applies only to a very small fraction of the sample. Tests using a null hypothesis of all panels being non-stationary would confidently reject the null for the first differences of all of our variables.

Hence, we conclude that our variables must be considered I(1); any standard OLS based estimation approach would most likely produce "spurious" results. A simple solution would be to estimate the relationship in first differences, but this would only deliver short-run dynamics (i. e. transitory effects) without telling us anything about the long-run relationship between charging infrastructure and EV registrations. 


\section{Table 2}

\begin{tabular}{lcccc}
\hline \hline & $\begin{array}{c}\text { Hadri }(2000) \\
\text { test statistic }(z)\end{array}$ & $\begin{array}{l}\text { Fraction of series } \\
\text { considered non-stationary } \\
\text { (at the 1 \%-level): }\end{array}$ \\
\hline levels (.) or $1^{\text {st }}$ diff. $(\Delta)$ & $\cdot$ & $\Delta$ &. & $\Delta$ \\
\hline Electric vehicles & $65.7^{* * *}$ & -15.6 & $74.1 \%$ & $0.0 \%$ \\
$\quad$ BEV & $66.2^{* * *}$ & -15.0 & $39.2 \%$ & $0.0 \%$ \\
PHEV & $45.6^{* * *}$ & -16.9 & $63.0 \%$ & $0.0 \%$ \\
$\begin{array}{l}\text { Number of charging stations } \\
\text { (= visibility effect) }\end{array}$ & $169.4^{* * *}$ & $22.0^{* * *}$ & $65.0 \%$ & $2.9 \%$ \\
$\begin{array}{l}\text { Overall charging capacity } \\
\text { (= capacity effect) }\end{array}$ & $153.2^{* * *}$ & $23.0^{* * *}$ & $61.8 \%$ & $2.5 \%$ \\
$\varnothing$ charging capacity & $103.3^{* * *}$ & -2.3 & $53.9 \%$ & $6.1 \%$ \\
(= abundance effect) & & & & \\
\hline
\end{tabular}

Note: $H_{0}$ : "All panels are stationary.", $H_{1}$ : "Some panels contain unit roots.", cross-sectional means removed, long-run variance specified using the Bartlett kernel with 4 lags, time-series unit root tests performed using the Stata package kpss by Baum (2018). ${ }^{* * *} p<0.001,{ }^{* *} p<0.01,{ }^{*} p<0.05$

If, however, the variables at hand are cointegrated, we can make use of an error correction model and characterize the relationship among these two variables $E V_{i, t}$ and $C_{i, t}$. Thereby we distinguish between the short-run dynamics that capture the impulse-response characteristics of the model and structural long-run effects that represent the equilibrium that both variables will return to after distortion has occurred. Even though Figure 2 in Section 3 already delivered the impression that some of the variables might follow a cointegrating equation with a stationary error term, we present the standard cointegration tests in Table 3. As they show strong indications of cointegration, we can make use of an error-correction model as displayed in Equation 3. Actually, the model works in itself as a kind of cointegration test: There can only be stable long-run effects if the error correction term $\phi_{i}$ is negative. Otherwise, the system would not return to equilibrium; hence, the variables would not be cointegrated.

As we use the infrastructure variables one by one, our specifications will contain only two variables at a time. Therefore, two considerations arise: First, could the analysis be biased due to omitted (stationary or non-stationary) variables, and second, what would happen to the estimates if we included further variables? As our two variables are cointegrated, the estimators are super-consistent (see Engle and Granger, 1987; Pesaran et al., 1999; Pesaran and Smith, 1995), meaning that the estimators converge with a relatively fast 


\section{Table 3}

Cointegration tests of EV registrations and charging infrastructure

\begin{tabular}{lll}
\hline \hline Cointegration tests & Statistic & Result \\
\hline Number of charging stations & (= visibility effect) & \\
Kao $(1999)$ & Augmented Dickey-Fuller t & $-73.75^{* * *}$ \\
Pedroni $(1999,2004)$ & Augmented Dickey-Fuller t & $-178.87^{* * *}$ \\
Westerlund (2005) & Variance ratio & $-38.43^{* * *}$ \\
\hline Overall charging capacity & (= capacity effect) & \\
Kao (1999) & Augmented Dickey-Fuller t & $-74.53^{* * *}$ \\
Pedroni (1999, 2004) & Augmented Dickey-Fuller t & $-179.98^{* * *}$ \\
Westerlund $(2005)$ & Variance ratio & $-38.71^{* * *}$ \\
\hline$\varnothing$ charging capacity $(=$ abundance effect $)$ & \\
Kao (1999) & Augmented Dickey-Fuller t & $-73.77^{* * *}$ \\
Pedroni $(1999,2004)$ & Augmented Dickey-Fuller t & $-176.93^{* * *}$ \\
Westerlund $(2005)$ & Variance ratio & $-37.63^{* * *}$ \\
\hline \hline
\end{tabular}

Note: $H_{0}$ : "No cointegration", $H_{1}$ : "Some (or all) regions in the panel are cointegrated", cross-sectional means removed, time trends included in Westerlund and Pedroni test. ${ }^{* * *} p<0.001,{ }^{* *} p<0.01$, ${ }^{*}$ $p<0.05$

rate to their equilibrium values (see Stock (1987)). Even though we only consider two variables at once, the estimators are reliable due to the property of super-consistency.

We previously mentioned that cointegrated variables lead to a stationary error term; therefore, the addition of a further non-stationary variable would lead to a non-stationary error term. This means we would fail to detect the cointegrating process between our variables of interest and might obtain spurious estimates. Bonham and Cohen (2001) even argue that there is no necessity to include further stationary variables even if the explanatory variables of charging infrastructure correlate with the error term. If there is a cointegrating relationship between EV registrations and the variables of charging infrastructure, then the stationary process will also exist in model extensions, meaning that an addition of further variables will not lead to a change in the estimates of our variables of interest (see Lütkepohl, 2007).

\subsubsection{Cross-sectional dependence}

A standard ARDL model in error correction form is applicable for non-stationary data and allows for estimations of short- and long-run effects. However, the issue of cross-sectional dependence remains. We have good reasons to believe that our variables will be subject to 
general movements over time that affect all or at least groups of regions. A part of this phenomenon might be explained by spatial spillover effects, e. g. when households tend to go for electric cars because they observe a rising EV density in their neighborhoods (see, e. g., Axsen et al., 2017); another part might be due to common factors, e. g. the release of new car types or federal/state policies. Table 4 shows the standard test for cross-sectional independence by Pesaran (2004), indicating that this issue must be considered in our analysis. $^{15}$

\section{Table 4}

Tests for cross-sectional independence

\begin{tabular}{llll}
\hline \hline Model & $\begin{array}{l}\text { Number of charg- } \\
\text { ing stations } \\
\text { (= visibility effect })\end{array}$ & $\begin{array}{l}\text { Overall charging } \\
\text { capacity } \\
\text { (= capacity effect })\end{array}$ & $\begin{array}{l}\varnothing \text { charging capacity } \\
(=\text { abund. effect })\end{array}$ \\
\hline without augmentation & $308.87^{* * *}$ & $272.89^{* * *}$ & $321.77^{* * *}$ \\
with 2-digit means & $13.37^{* * *}$ & $12.92^{* * *}$ & $10.75^{* * *}$ \\
with 2-digit means + 1 lag & $2.26^{*}$ & $2.12^{*}$ & $2.21^{*}$ \\
with 2-digit means + 2 lags & -0.01 & -0.27 & 0.50 \\
with 2-digit means + 3 lags & -0.06 & -0.28 & 0.57 \\
with 2-digit means + 4 lags & -0.05 & -0.28 & 0.64 \\
(with global means +4 lags) & $28.77^{* * *}$ & $29.07^{* * *}$ & $29.10^{* * *}$ \\
\hline \hline
\end{tabular}

Note: The test is based on the ARDL model from Equation 1 using EV registrations. $H_{0}$ : "Cross-sectional independence." $H_{1}$ : "Cross-sectional dependence." ${ }^{* * *} p<0.001,{ }^{* *} p<0.01,{ }^{*} p<0.05$

An estimation failing to take care of cross-sectional dependence would yield biased results. Chudik and Pesaran (2015) point out that the inclusion of cross-sectional means and a sufficient number of lags thereof in the ARDL model solves the problem. This approach is referred to as cross-sectional augmented ARDL (or CS-ARDL). We modify this procedure by including means for the respective 2-digit-level rather than global means. We experience that this modification depresses the test statistics even more strongly than the basic approach by Chudik and Pesaran (2015). We suppose that this is due to our geographically very fine-grained data. If means are taken at a level too broad, any spatial patterns might be smoothed away so that the inclusion is less helpful in identifying rather local common effects. ${ }^{16}$ Concerning the number of lags, Chudik and Pesaran (2015) suggest using the integer part of $T^{1 / 3}$ as a rule of thumb; this means four lags in our case

\footnotetext{
${ }^{15}$ We deploy the Stata package $x t c s d$ by De Hoyos and Sarafidis (2006).

${ }^{16}$ We also ran the analysis using global means as in Chudik and Pesaran (2015). The test score drops but stays statistically significant.
} 
(i. e., $p_{\overline{\mathbf{z}}} \equiv 4$ in Equation 3). ${ }^{17}$ We do not reject the null hypothesis of cross-sectional independence as soon as the proper augmentation is in place.

\subsubsection{Heterogeneity}

There are good reasons to conjecture that the relationship between EV registrations and variables of charging infrastructure might be heterogeneous across regions. While the technical conditions should be basically the same for all car owners, there might be differences in the share of private charging or socio-demographic characteristics. Hence, regional EV registrations might react stronger (or weaker) to changes in the availability of charging infrastructure. Such heterogeneous effects might apply to short- and long-run coefficients as well as to the error-correction term; hence, regions might be characterized by different equilibria (some might have none at all). Negligence of such heterogeneity would lead to inconsistent estimation outcomes (see Pesaran and Smith, 1995).

The standard approach to estimate Equation 3 would be a dynamic fixed effects (DFE) estimator ${ }^{18}$ that allows region-specific intercepts but assumes homogeneous slope parameters. However, heterogeneity can be implemented: Pesaran et al. (1999) propose the pooled mean group (PMG) estimator that allows the short-run coefficients and the error correction parameter to be region-specific by estimating them separately and pooling the results afterward. The long-term coefficients are assumed to be homogeneous. The mean group (MG) estimator by Pesaran and Smith (1995) goes one step further and allows even heterogeneous long-run coefficients. We will use all three estimators and deploy Hausman tests in order to decide which model fits our data best.

\section{Results}

\subsection{Baseline}

We start by estimating Equation 3 using overall EV registrations and the abundance measure of infrastructure as a baseline. We present the results for all three estimators (DFE, PMG and MG) in Table 5. ${ }^{19}$ Before we turn to the coefficients in Table 5 though, we must refer to the Hausman test results at the bottom of the table in order to determine

\footnotetext{
${ }^{17}$ We include the current and 2 lags of the first difference of $E V_{i, t}$ and $C_{i, t}$ and 4 lags of their cross-sectional means.

18 See, e. g., Baltagi et al. (2000) for an overview.

19 We use the Stata package xtpmg by Blackburne III and Frank (2007).
} 
which estimator is most appropriate. PMG and DFE impose restrictions on the longrun (and in the case of DFE even on the short-run) coefficients and are, therefore, only consistent if the respective assumptions of parameter homogeneity are indeed valid. If they are, the respective estimator is efficient; if not, MG should be deployed as it does not impose any restrictions and is consistent in either case (see Blackburne III and Frank, 2007). The null hypothesis of our Hausman test is that there are no systematic differences between coefficients when comparing PMG and DFE to MG, respectively. If $H_{0}$ is rejected, we go for the more efficient estimator; otherwise we stick with the always-consistent MG.

As the $p$-values in Table 5 indicate, there are no systematic differences between the estimators, neither between DFE and MG nor between PMG and MG. Hence, all three estimators are consistent, but MG is the least efficient one. Running the Hausman test for PMG and DFE does not yield a meaningful test result as the variance of the efficient estimator (DFE) exceeds the one of the consistent estimator (PMG). Greene (2003, p. 699) suggests not to reject the null in those cases and to go for the efficient estimator. Hence, the simple assumption of homogeneous slope parameters seems appropriate for our kind of data. Nonetheless, we show all three specifications in order to demonstrate the robustness properties of our analyses. We will see that our main conclusions hold irrespective of the assumptions made concerning heterogeneity (the magnitudes vary though).

Table 5 shows the results with and without cross-sectional augmentation. The findings are mainly in line with our expectations: First of all, the error-correction term is negative and significant in all specifications; hence, the two variables do have a structural equilibrium that will be reachieved in the long run after a disturbance has occurred.

Concerning the long-run results, there is a positive and mostly significant relationship between EV registrations and our abundance measure of charging infrastructure $\left(C_{a}\right)$ in the unaugmented regressions (Columns (1), (3), and (5)). However, we observe that the coefficients get much smaller once cross-sectional means are included (Columns (2), (4), and (6)). If we take the DFE specification seriously (according to the Hausman tests), it will take 33 more kilowatts on average (i. e. 1/0.03) in order to permanently observe one more EV in 1,000 registrations per month. Basically, this would mean that almost every existing charging station (providing an average of $24 \mathrm{~kW}$; see Table 1) must be replaced by a fast charger. Would we not take cross-sectional dependence into account, the abundance effect would erroneously appear much larger. The corresponding short-run coefficients for $C_{a}$ are mostly insignificant in the augmented specifications and show very unstable 
Table 5

Results $A-E V$ registrations and Ø charging capacity (= abundance effect)

\begin{tabular}{|c|c|c|c|c|c|c|}
\hline \multirow[t]{2}{*}{$\begin{array}{l}\text { Dep. var.: } \\
\Delta E V\end{array}$} & \multicolumn{2}{|c|}{$\begin{array}{l}\text { Dynamic fixed effects } \\
\text { (DFE) }\end{array}$} & \multicolumn{2}{|c|}{$\begin{array}{l}\text { Pooled mean group } \\
(\mathrm{PMG})\end{array}$} & \multicolumn{2}{|c|}{$\begin{array}{l}\text { Mean group } \\
(\mathrm{MG})\end{array}$} \\
\hline & (1) & $(2)$ & (3) & $(4)$ & $(5)$ & (6) \\
\hline \multicolumn{7}{|l|}{ Long-run } \\
\hline $\begin{array}{l}\varnothing \text { charg. capacity }\left(C_{a}\right) \\
(=\text { abundance })\end{array}$ & $\begin{array}{l}0.37^{* * *} \\
(0.01)\end{array}$ & $\begin{array}{l}0.03^{*} \\
(0.01)\end{array}$ & $\begin{array}{l}0.51^{* * *} \\
(0.01)\end{array}$ & $\begin{array}{l}0.01^{* * *} \\
(0.00)\end{array}$ & $\begin{array}{l}0.75 \\
(1.37)\end{array}$ & $\begin{array}{l}0.16 \\
(0.16)\end{array}$ \\
\hline Error-correction term & $\begin{array}{l}-0.38^{* * *} \\
(0.01)\end{array}$ & $\begin{array}{l}-0.56^{* * *} \\
(0.01)\end{array}$ & $\begin{array}{l}-0.34^{* * *} \\
(0.01)\end{array}$ & $\begin{array}{l}-0.96^{* * *} \\
(0.02)\end{array}$ & $\begin{array}{l}-0.46^{* * *} \\
(0.01)\end{array}$ & $\begin{array}{l}-1.04^{* * *} \\
(0.02)\end{array}$ \\
\hline \multicolumn{7}{|l|}{ Short-run } \\
\hline $1 . \Delta E V$ & $\begin{array}{l}-0.30^{* * *} \\
(0.01)\end{array}$ & $\begin{array}{l}-0.19^{* * *} \\
(0.01)\end{array}$ & $\begin{array}{l}-0.38^{* * *} \\
(0.01)\end{array}$ & $\begin{array}{l}0.02 \\
(0.01)\end{array}$ & $\begin{array}{l}-0.31^{* * * *} \\
(0.01)\end{array}$ & $\begin{array}{l}0.06^{* * *} \\
(0.01)\end{array}$ \\
\hline $12 . \Delta E V$ & $\begin{array}{l}-0.12^{* * *} \\
(0.01)\end{array}$ & $\begin{array}{l}-0.08^{* * *} \\
(0.01)\end{array}$ & $\begin{array}{l}-0.22^{* * *} \\
(0.01)\end{array}$ & $\begin{array}{l}-0.02^{*} \\
(0.01)\end{array}$ & $\begin{array}{l}-0.18^{* * *} \\
(0.01)\end{array}$ & $\begin{array}{l}0.00 \\
(0.01)\end{array}$ \\
\hline$\Delta C_{a}$ & $\begin{array}{l}-0.05^{* *} \\
(0.02)\end{array}$ & $\begin{array}{l}0.01 \\
(0.01)\end{array}$ & $\begin{array}{l}0.33 \\
(0.26)\end{array}$ & $\begin{array}{l}0.40^{*} \\
(0.19)\end{array}$ & $\begin{array}{l}0.23 \\
(0.22)\end{array}$ & $\begin{array}{l}0.26 \\
(0.20)\end{array}$ \\
\hline l. $\Delta C_{a}$ & $\begin{array}{l}-0.08^{* * *} \\
(0.02)\end{array}$ & $\begin{array}{c}-0.03^{*} \\
(0.02)\end{array}$ & $\begin{array}{l}0.12 \\
(0.17)\end{array}$ & $\begin{array}{l}-0.02 \\
(0.11)\end{array}$ & $\begin{array}{l}0.11 \\
(0.16)\end{array}$ & $\begin{array}{l}-0.03 \\
(0.13)\end{array}$ \\
\hline $12 . \Delta C_{a}$ & $\begin{array}{l}-0.07^{* * *} \\
(0.02)\end{array}$ & $\begin{array}{l}-0.01 \\
(0.02)\end{array}$ & $\begin{array}{l}-0.26 \\
(0.29)\end{array}$ & $\begin{array}{c}-0.22 \\
(0.20)\end{array}$ & $\begin{array}{c}-0.23 \\
(0.31)\end{array}$ & $\begin{array}{c}-0.23 \\
(0.23)\end{array}$ \\
\hline \multicolumn{7}{|l|}{ CS-means $\left(\overline{\boldsymbol{Z}}_{t}\right)$} \\
\hline$\overline{E V}$ & - & $\begin{array}{l}0.82^{* * *} \\
(0.01)\end{array}$ & - & $\begin{array}{l}0.91^{* * *} \\
(0.03)\end{array}$ & - & $\begin{array}{l}0.91^{* * *} \\
(0.03)\end{array}$ \\
\hline $1 . \overline{E V}$ & - & $\begin{array}{l}-0.15^{* * *} \\
(0.01)\end{array}$ & - & $\begin{array}{l}-0.02 \\
(0.02)\end{array}$ & - & $\begin{array}{l}0.00 \\
(0.02)\end{array}$ \\
\hline $12 . \overline{E V}$ & - & $\begin{array}{l}-0.08^{* * *} \\
(0.01)\end{array}$ & - & $\begin{array}{l}0.05^{* *} \\
(0.02)\end{array}$ & - & $\begin{array}{l}0.08^{* * *} \\
(0.02)\end{array}$ \\
\hline $13 . \overline{E V}$ & - & $\begin{array}{l}-0.06^{* * *} \\
(0.01)\end{array}$ & - & $\begin{array}{l}0.02 \\
(0.02)\end{array}$ & - & $\begin{array}{l}0.04 \\
(0.02)\end{array}$ \\
\hline $14 . \overline{E V}$ & - & $\begin{array}{l}0.00 \\
(0.01)\end{array}$ & - & $\begin{array}{l}0.01 \\
(0.02)\end{array}$ & - & $\begin{array}{l}0.00 \\
(0.02)\end{array}$ \\
\hline $\bar{C}_{a}$ & - & $\begin{array}{l}0.01 \\
(0.03)\end{array}$ & - & $\begin{array}{l}-0.19 \\
(0.25)\end{array}$ & - & $\begin{array}{l}-0.25 \\
(0.24)\end{array}$ \\
\hline $1 . \bar{C}_{a}$ & - & $\begin{array}{l}-0.01 \\
(0.04)\end{array}$ & - & $\begin{array}{l}0.32 \\
(0.34)\end{array}$ & - & $\begin{array}{l}0.33 \\
(0.33)\end{array}$ \\
\hline $12 . \bar{C}_{a}$ & - & $\begin{array}{l}0.00 \\
(0.04)\end{array}$ & - & $\begin{array}{l}-0.13 \\
(0.44)\end{array}$ & - & $\begin{array}{l}-0.22 \\
(0.43)\end{array}$ \\
\hline $13 . \bar{C}_{a}$ & - & $\begin{array}{l}-0.01 \\
(0.04)\end{array}$ & - & $\begin{array}{l}0.21 \\
(0.39)\end{array}$ & - & $\begin{array}{l}0.25 \\
(0.39)\end{array}$ \\
\hline $14 . \bar{C}_{a}$ & - & $\begin{array}{l}0.03 \\
(0.03)\end{array}$ & - & $\begin{array}{l}0.01 \\
(0.42)\end{array}$ & - & $\begin{array}{l}-0.08 \\
(0.46)\end{array}$ \\
\hline Constant & $\begin{array}{l}1.24^{* * *} \\
(0.08)\end{array}$ & $\begin{array}{l}-0.28 \\
(0.15)\end{array}$ & $\begin{array}{l}1.13^{* * *} \\
(0.11)\end{array}$ & $\begin{array}{l}-4.70 \\
(6.20)\end{array}$ & $\begin{array}{l}1.11 \\
(3.84)\end{array}$ & $\begin{array}{l}-4.44 \\
(7.48)\end{array}$ \\
\hline Hausman test $p$-value & & 0.39 & & 0.35 & & - \\
\hline
\end{tabular}

Note: Standard errors in parentheses. Groups: 594, Obs.: 40,392. *** $p<0.001,{ }^{* *} p<0.01,{ }^{*} p<0.05$ 
signs. Hence, there is no evidence of a transitory impulse-response characteristic between charging infrastructure and EV registrations.

We must conclude that the abundance effect of charging infrastructure gets very small as soon as the cross-sectional augmentation comes in. This suggests that the variation in EV registrations is, to a large, extent driven by unobservable common factors and spatial spillovers. The contemporary terms of $\overline{\mathbf{Z}}_{t}$ show very large positive coefficients for the number of EV registrations before they turn significantly negative in the subsequent months and then eventually disappear. The coefficients for the cross-sectional means $\bar{C}_{a}$, however, are insignificant across the board. Hence, the very strong impact of $\overline{E V}$ is what makes the coefficients drop between specification 1 and 2 .

This underlines one of the guesses we have made earlier (see Section 2): Consumers decide to buy an EV when the peer pressure is high enough; i. e. the more they get into contact with electric cars, not only in their neighborhood but also in the media, etc. The implication of our main result, however, is in no way that charging infrastructure would be irrelevant for potential consumers. There is a stable long-run relationship, even though consumers do not seem to respond to additional charging stations directly. The main motivation seems to come from cars, not from stations.

In fact, there is even a causal relationship: According to the Granger representation theorem (see Engle and Granger, 1987), cointegration means causation in at least one direction. Hence, our negative and highly significant error-correction term indicates not only that the two variables are indeed cointegrated, it is at the same time evidence that one of the two variables will adjust to disturbances from equilibrium while the other one may be weakly exogenous. In order to check for the direction of Granger causation, we reran the analysis in the fashion of a vector error-correction model (VECM). ${ }^{20}$ We find that car registrations adjust strongly to deviations from long-run equilibrium in all of the model specifications whereas the charging infrastructure variables hardly move at all. Hence, Granger causation clearly runs from infrastructure to car registrations, which is the mechanism proposed in the literature.

\subsection{Robustness}

We have shown in the last section that our results hold irrespective of the assumptions concerning parameter homogeneity; the three estimation techniques lead to very similar

\footnotetext{
$\overline{20}$ The results are not shown here for the sake of brevity but are available from the authors upon request.
} 
conclusions. This section will provide further specifications in order to prove the robustness of our results.

We modify the analyses along two lines of argument that have already been put down in Section 3: First, we argue that consumers might not only react to the abundance of charging infrastructure; they might already be attracted by the mere existence of charging stations (visibility effect) or by the overall charging capacity in their neighborhood (capacity effect). We will show the different results in subsection 5.2.1. Second, consumers of plugin-hybrid electric vehicles (PHEVs) might differ from those who are interested in purely battery electric vehicles (BEVs) when it comes to the availability of charging infrastructure. We will, therefore, restrict the sample to BEVs and PHEVs, respectively, and present the results in subsection 5.2.2.

\subsubsection{Different measures of infrastructure}

Tables 6 and 7 show the visibility and the capacity effect of charging infrastructure on EV registrations. The results are similar but appear slightly weaker in comparison to the abundance effect. The coefficients of interest for $C_{v}$ and $C_{c}$ turn insignificant after cross-sectional augmentation. ${ }^{21}$ Interestingly, if we revisit Equation $3, \hat{\beta}_{1}$ is now virtually zero, which means that EV registrations in the long-run equilibrium are independent of the number of charging stations and of overall regional charging capacities. The unaugmented regressions would show a much different picture, but as soon as cross-sectional dependence is accounted for, EV registrations simply follow a common trend that regions can only break out of by installing additional fast chargers, as indicated by the abundance effect in Section 5.1.

This confirms our presumption that consumers do not necessarily react to additional chargers alone but take into account that only more powerful stations decrease their charging times and relax the bottleneck effect during peak times.

\subsubsection{Different types of electric vehicles}

The abundance effect for BEV and PHEV registrations is shown in Tables 8 and 9, respectively. We observe that the results for PHEV registrations are somewhat stronger than for BEVs. This applies also to the visibility and the capacity effect shown in Tables A1 - A4 in the Appendix.

\footnotetext{
$\overline{21}$ As before, the Hausman tests prefer DFE in both specifications.
} 
Table 6

Results $B-E V$ registrations and number of charging stations (= visibility effect)

\begin{tabular}{|c|c|c|c|c|c|c|}
\hline \multirow[t]{2}{*}{$\begin{array}{l}\text { Dep. var.: } \\
\Delta E V\end{array}$} & \multicolumn{2}{|c|}{$\begin{array}{l}\text { Dynamic fixed effects } \\
\text { (DFE) }\end{array}$} & \multicolumn{2}{|c|}{$\begin{array}{l}\text { Pooled mean group } \\
(\mathrm{PMG})\end{array}$} & \multicolumn{2}{|c|}{$\begin{array}{l}\text { Mean group } \\
(\mathrm{MG})\end{array}$} \\
\hline & (1) & $(2)$ & $(3)$ & $(4)$ & $(5)$ & (6) \\
\hline \multicolumn{7}{|l|}{ Long-run } \\
\hline $\begin{array}{l}\text { Charging stations }\left(C_{v}\right) \\
(=\text { visibility })\end{array}$ & $\begin{array}{l}0.56^{* * *} \\
(0.02)\end{array}$ & $\begin{array}{l}0.04 \\
(0.02)\end{array}$ & $\begin{array}{l}1.21^{* * *} \\
(0.02)\end{array}$ & $\begin{array}{l}-0.00 \\
(0.02)\end{array}$ & $\begin{array}{l}4.26^{* * *} \\
(1.19)\end{array}$ & $\begin{array}{l}0.11 \\
(0.16)\end{array}$ \\
\hline Error-correction term & $\begin{array}{l}-0.39 * * * \\
(0.01)\end{array}$ & $\begin{array}{l}-0.56^{* * *} \\
(0.01)\end{array}$ & $\begin{array}{l}-0.45^{* * *} \\
(0.01)\end{array}$ & $\begin{array}{l}-1.00^{* * *} \\
(0.02)\end{array}$ & $\begin{array}{l}-0.62^{* * *} \\
(0.01)\end{array}$ & $\begin{array}{l}-1.08^{* * *} \\
(0.02)\end{array}$ \\
\hline \multicolumn{7}{|l|}{ Short-run } \\
\hline $1 . \Delta E V$ & $\begin{array}{l}-0.29^{* * *} \\
(0.01)\end{array}$ & $\begin{array}{l}-0.19^{* * *} \\
(0.01)\end{array}$ & $\begin{array}{l}-0.31^{* * *} \\
(0.01)\end{array}$ & $\begin{array}{l}0.04^{* * *} \\
(0.01)\end{array}$ & $\begin{array}{l}-0.20^{* * *} \\
(0.01)\end{array}$ & $\begin{array}{l}0.08^{* * *} \\
(0.01)\end{array}$ \\
\hline $12 . \Delta E V$ & $\begin{array}{l}-0.12^{* * *} \\
(0.01)\end{array}$ & $\begin{array}{l}-0.08^{* * *} \\
(0.01)\end{array}$ & $\begin{array}{l}-0.18^{* * *} \\
(0.01)\end{array}$ & $\begin{array}{l}-0.01 \\
(0.01)\end{array}$ & $\begin{array}{l}-0.13^{* * *} \\
(0.01)\end{array}$ & $\begin{array}{l}0.02^{*} \\
(0.01)\end{array}$ \\
\hline$\Delta C_{v}$ & $\begin{array}{l}0.16^{* * *} \\
(0.05)\end{array}$ & $\begin{array}{l}0.02 \\
(0.05)\end{array}$ & $\begin{array}{l}0.32^{*} \\
(0.13)\end{array}$ & $\begin{array}{l}0.08 \\
(0.16)\end{array}$ & $\begin{array}{l}-0.80^{* * *} \\
(0.20)\end{array}$ & $\begin{array}{l}-0.08 \\
(0.19)\end{array}$ \\
\hline 1. $\Delta C_{v}$ & $\begin{array}{l}0.03 \\
(0.05)\end{array}$ & $\begin{array}{l}-0.05 \\
(0.05)\end{array}$ & $\begin{array}{l}0.39 \\
(0.20)\end{array}$ & $\begin{array}{l}0.10 \\
(0.17)\end{array}$ & $\begin{array}{l}-0.60^{* *} \\
(0.21)\end{array}$ & $\begin{array}{l}0.01 \\
(0.22)\end{array}$ \\
\hline $12 . \Delta C_{v}$ & $\begin{array}{l}0.04 \\
(0.05)\end{array}$ & $\begin{array}{l}0.02 \\
(0.05)\end{array}$ & $\begin{array}{l}0.49^{*} \\
(0.23)\end{array}$ & $\begin{array}{l}0.27 \\
(0.21)\end{array}$ & $\begin{array}{l}-0.32 \\
(0.25)\end{array}$ & $\begin{array}{l}0.19 \\
(0.23)\end{array}$ \\
\hline \multicolumn{7}{|l|}{ CS-means $\left(\overline{\boldsymbol{Z}}_{t}\right)$} \\
\hline$\overline{E V}$ & - & $\begin{array}{l}0.81^{* * *} \\
(0.01)\end{array}$ & - & $\begin{array}{l}0.91^{* * *} \\
(0.03)\end{array}$ & - & $\begin{array}{l}0.90^{* * *} \\
(0.03)\end{array}$ \\
\hline $1 . \overline{E V}$ & - & $\begin{array}{l}-0.15^{* * *} \\
(0.01)\end{array}$ & - & $\begin{array}{l}-0.02 \\
(0.02)\end{array}$ & - & $\begin{array}{l}0.02 \\
(0.02)\end{array}$ \\
\hline $12 . \overline{E V}$ & - & $\begin{array}{l}-0.08^{* * *} \\
(0.01)\end{array}$ & - & $\begin{array}{l}0.05^{* *} \\
(0.02)\end{array}$ & - & $\begin{array}{l}0.07^{* * *} \\
(0.02)\end{array}$ \\
\hline $13 . \overline{E V}$ & - & $\begin{array}{l}-0.06^{* * *} \\
(0.01)\end{array}$ & - & $\begin{array}{l}0.00 \\
(0.02)\end{array}$ & - & $\begin{array}{l}0.03 \\
(0.02)\end{array}$ \\
\hline $14 . \overline{E V}$ & - & $\begin{array}{l}-0.00 \\
(0.01)\end{array}$ & - & $\begin{array}{l}-0.01 \\
(0.02)\end{array}$ & - & $\begin{array}{l}-0.00 \\
(0.02)\end{array}$ \\
\hline $\bar{C}_{v}$ & - & $\begin{array}{l}2.94^{* *} \\
(0.91)\end{array}$ & - & $\begin{array}{l}-0.59 \\
(2.91)\end{array}$ & - & $\begin{array}{l}-1.61 \\
(2.89)\end{array}$ \\
\hline $1 . \bar{C}_{v}$ & - & $\begin{array}{l}-0.96 \\
(1.38)\end{array}$ & - & $\begin{array}{l}0.34 \\
(3.97)\end{array}$ & - & $\begin{array}{l}0.62 \\
(3.80)\end{array}$ \\
\hline $12 . \bar{C}_{v}$ & - & $\begin{array}{l}-1.48 \\
(1.47)\end{array}$ & - & $\begin{array}{l}2.35 \\
(4.81)\end{array}$ & - & $\begin{array}{l}1.58 \\
(4.51)\end{array}$ \\
\hline $13 . \bar{C}_{v}$ & - & $\begin{array}{l}1.17 \\
(1.52)\end{array}$ & - & $\begin{array}{l}-1.71 \\
(4.32)\end{array}$ & - & $\begin{array}{l}-2.80 \\
(4.64)\end{array}$ \\
\hline $14 . \bar{C}_{v}$ & - & $\begin{array}{l}-1.14 \\
(1.01)\end{array}$ & - & $\begin{array}{l}3.23 \\
(3.27)\end{array}$ & - & $\begin{array}{l}2.75 \\
(3.54)\end{array}$ \\
\hline Constant & $\begin{array}{l}1.68^{* * * *} \\
(0.07)\end{array}$ & $\begin{array}{l}0.02 \\
(0.07)\end{array}$ & $\begin{array}{l}1.00^{* * *} \\
(0.14)\end{array}$ & $\begin{array}{l}-0.21 \\
(0.12)\end{array}$ & $\begin{array}{l}0.38 \\
(0.28)\end{array}$ & $\begin{array}{c}-0.62^{*} \\
(0.29)\end{array}$ \\
\hline Hausman test $p$-value & & 0.66 & & 0.50 & & - \\
\hline
\end{tabular}

Note: Standard errors in parentheses. Groups: 594, Obs.: 40,392. *** $p<0.001,{ }^{* *} p<0.01,{ }^{*} p<0.05$ 
Table 7

Results $C-E V$ registrations and overall charging capacity (= capacity effect)

\begin{tabular}{|c|c|c|c|c|c|c|}
\hline \multirow[t]{2}{*}{$\begin{array}{l}\text { Dep. var.: } \\
\Delta E V\end{array}$} & \multicolumn{2}{|c|}{$\begin{array}{l}\text { Dynamic fixed effects } \\
\text { (DFE) }\end{array}$} & \multicolumn{2}{|c|}{$\begin{array}{l}\text { Pooled mean group } \\
\text { (PMG) }\end{array}$} & \multicolumn{2}{|c|}{$\begin{array}{l}\text { Mean group } \\
\text { (MG) }\end{array}$} \\
\hline & (1) & $(2)$ & (3) & $(4)$ & (5) & $(6)$ \\
\hline \multicolumn{7}{|l|}{ Long-run } \\
\hline$\sum$ charg. capacity $\left(C_{c}\right)$ & $\begin{array}{l}0.03^{* * *} \\
(0.00)\end{array}$ & $\begin{array}{l}0.00 \\
(0.00)\end{array}$ & $\begin{array}{l}0.04^{* * *} \\
(0.00)\end{array}$ & $\begin{array}{l}0.00^{*} \\
(0.00)\end{array}$ & $\begin{array}{l}0.33 \\
(0.20)\end{array}$ & $\begin{array}{l}0.03 \\
(0.03)\end{array}$ \\
\hline Error-correction term & $\begin{array}{l}-0.39^{* * *} \\
(0.01)\end{array}$ & $\begin{array}{l}-0.56^{* * *} \\
(0.01)\end{array}$ & $\begin{array}{l}-0.43^{* * *} \\
(0.01)\end{array}$ & $\begin{array}{l}-1.01^{* * *} \\
(0.01)\end{array}$ & $\begin{array}{l}-0.62^{* * *} \\
(0.01)\end{array}$ & $\begin{array}{l}-1.08^{* * *} \\
(0.01)\end{array}$ \\
\hline \multicolumn{7}{|l|}{ Short-run } \\
\hline 1. $\Delta E V$ & $\begin{array}{l}-0.29 * * * \\
(0.01)\end{array}$ & $\begin{array}{l}-0.19^{* * *} \\
(0.01)\end{array}$ & $\begin{array}{l}-0.32^{* * *} \\
(0.01)\end{array}$ & $\begin{array}{l}0.04^{* * *} \\
(0.01)\end{array}$ & $\begin{array}{l}-0.21^{* * *} \\
(0.01)\end{array}$ & $\begin{array}{l}0.08^{* * *} \\
(0.01)\end{array}$ \\
\hline $12 . \Delta E V$ & $\begin{array}{l}-0.11^{* * *} \\
(0.01)\end{array}$ & $\begin{array}{l}-0.08^{* * *} \\
(0.01)\end{array}$ & $\begin{array}{l}-0.19^{* * *} \\
(0.01)\end{array}$ & $\begin{array}{l}-0.00 \\
(0.01)\end{array}$ & $\begin{array}{l}-0.13^{* * *} \\
(0.01)\end{array}$ & $\begin{array}{l}0.02^{*} \\
(0.01)\end{array}$ \\
\hline$\Delta C_{c}$ & $\begin{array}{l}0.00 \\
(0.00)\end{array}$ & $\begin{array}{l}0.00 \\
(0.00)\end{array}$ & $\begin{array}{l}0.02^{* *} \\
(0.01)\end{array}$ & $\begin{array}{l}-0.00 \\
(0.01)\end{array}$ & $\begin{array}{l}-0.05^{*} \\
(0.02)\end{array}$ & $\begin{array}{l}-0.04 \\
(0.03)\end{array}$ \\
\hline 1. $\Delta C_{c}$ & $\begin{array}{l}-0.00 \\
(0.00)\end{array}$ & $\begin{array}{l}-0.00 \\
(0.00)\end{array}$ & $\begin{array}{l}0.03^{*} \\
(0.02)\end{array}$ & $\begin{array}{l}-0.00 \\
(0.01)\end{array}$ & $\begin{array}{l}-0.03 \\
(0.02)\end{array}$ & $\begin{array}{l}-0.03 \\
(0.03)\end{array}$ \\
\hline $12 . \Delta C_{c}$ & $\begin{array}{l}-0.00 \\
(0.00) \\
\end{array}$ & $\begin{array}{l}0.00 \\
(0.00) \\
\end{array}$ & $\begin{array}{l}0.05^{*} \\
(0.03) \\
\end{array}$ & $\begin{array}{l}0.03 \\
(0.02) \\
\end{array}$ & $\begin{array}{l}0.00 \\
(0.03) \\
\end{array}$ & $\begin{array}{l}-0.01 \\
(0.03) \\
\end{array}$ \\
\hline \multicolumn{7}{|l|}{ CS-means $\left(\overline{\boldsymbol{Z}}_{t}\right)$} \\
\hline$\overline{E V}$ & - & $\begin{array}{l}0.81^{* * *} \\
(0.01)\end{array}$ & - & $\begin{array}{l}0.90^{* * *} \\
(0.03)\end{array}$ & - & $\begin{array}{l}0.90^{* * *} \\
(0.03)\end{array}$ \\
\hline 1. $\overline{E V}$ & - & $\begin{array}{l}-0.15^{* * *} \\
(0.01)\end{array}$ & - & $\begin{array}{l}-0.01 \\
(0.02)\end{array}$ & - & $\begin{array}{l}0.02 \\
(0.02)\end{array}$ \\
\hline $12 . \overline{E V}$ & - & $\begin{array}{l}-0.08^{* * *} \\
(0.01)\end{array}$ & - & $\begin{array}{l}0.06^{* *} \\
(0.02)\end{array}$ & - & $\begin{array}{l}0.08^{* * *} \\
(0.02)\end{array}$ \\
\hline $13 . \overline{E V}$ & - & $\begin{array}{l}-0.06^{* * *} \\
(0.01)\end{array}$ & - & $\begin{array}{l}0.01 \\
(0.02)\end{array}$ & - & $\begin{array}{l}0.02 \\
(0.02)\end{array}$ \\
\hline $14 . \overline{E V}$ & - & $\begin{array}{l}-0.00 \\
(0.01)\end{array}$ & - & $\begin{array}{l}-0.00 \\
(0.02)\end{array}$ & - & $\begin{array}{l}-0.00 \\
(0.02)\end{array}$ \\
\hline $\bar{C}_{c}$ & - & $\begin{array}{l}0.11^{*} \\
(0.04)\end{array}$ & - & $\begin{array}{l}-0.00 \\
(0.12)\end{array}$ & - & $\begin{array}{l}0.05 \\
(0.12)\end{array}$ \\
\hline l. $\bar{C}_{c}$ & - & $\begin{array}{l}-0.04 \\
(0.07)\end{array}$ & - & $\begin{array}{l}0.07 \\
(0.14)\end{array}$ & - & $\begin{array}{l}0.07 \\
(0.14)\end{array}$ \\
\hline $12 . \bar{C}_{c}$ & - & $\begin{array}{l}-0.05 \\
(0.07)\end{array}$ & - & $\begin{array}{l}0.02 \\
(0.21)\end{array}$ & - & $\begin{array}{l}-0.05 \\
(0.20)\end{array}$ \\
\hline $13 . \bar{C}_{c}$ & - & $\begin{array}{l}0.07 \\
(0.07)\end{array}$ & - & $\begin{array}{l}-0.05 \\
(0.21)\end{array}$ & - & $\begin{array}{l}-0.05 \\
(0.21)\end{array}$ \\
\hline $14 . \bar{C}_{c}$ & - & $\begin{array}{l}-0.05 \\
(0.05) \\
\end{array}$ & - & $\begin{array}{l}0.14 \\
(0.14) \\
\end{array}$ & - & $\begin{array}{l}0.11 \\
(0.15) \\
\end{array}$ \\
\hline Constant & $\begin{array}{l}1.67^{* * *} \\
(0.07) \\
\end{array}$ & $\begin{array}{l}0.02 \\
(0.07) \\
\end{array}$ & $\begin{array}{l}1.26^{* * *} \\
(0.12) \\
\end{array}$ & $\begin{array}{l}-0.30^{*} \\
(0.14) \\
\end{array}$ & $\begin{array}{l}-0.98 \\
(1.14)\end{array}$ & $\begin{array}{l}-1.20 \\
(1.12)\end{array}$ \\
\hline Hausman test $p$-value & & 0.26 & & 0.27 & & - \\
\hline
\end{tabular}

Note: Standard errors in parentheses. Groups: 594, Obs.: 40,392. ${ }^{* * *} p<0.001,{ }^{* *} p<0.01,{ }^{*} p<0.05$ 
Even though the differences are not very large, this supports our initial guess: While BEV consumers depend completely on charging infrastructure, prospective PHEV consumers can always run their car on fossil fuel if needed. Their freedom to switch off the electric mode makes them more risk-taking when it comes to the availability of charging infrastructure. They might find additional or faster charging infrastructure motivating for their decisionmaking process. Prospective BEV consumers, however, stay rather skeptical even if the charging infrastructure in their neighborhood increases. They will hardly buy an electric car as long as they do not have their own charging facility or sufficient public charging infrastructure.

\section{Conclusion}

A quick transition from mostly combustion-based to electric vehicles might be crucial if the ambitious carbon dioxide reduction plans shall be met within the next decades. In this paper, we investigate the relationship between electric car registrations of private households and charging infrastructure in Germany by means of cointegration analysis. To the best of our knowledge, this is the methodologically most sound empirical analysis of the matter as it takes care of non-stationarity, cross-sectional dependence, and possible heterogeneity. Consequently, our results are slightly less optimistic than others.

In any case, we find stable cointegrating relationships between different types of electric vehicles and different measures of charging infrastructure. We are also confident that Granger causality runs from charging infrastructure to EV registrations, i. e. the number of cars registered each month eventually adjusts to the charging infrastructure measures. This is in line with the consumer choice literature.

However, the long-run relationship between EV registrations and charging infrastructure seems rather weak. More and better infrastructure might lead to persistently higher EV registrations in a region, but only at a very low scale. The effects are somewhat stronger for PHEVs than for pure BEVs. Also, the charging capacities play an important role: We conclude that the visibility effect (i. e. the mere existence of charging stations) and the capacity effect (i. e. the accumulated charging capacity in a region) are less effective than the abundance effect (i. e. the average charging capacity in kilowatts per station). Hence, consumers seem to be aware of the fact that public chargers are subject to bottleneck effects during peak times and, therefore, seem to prefer a small number of fast chargers to a large number of slow ones. 
This study captures electric mobility in its very early stages. Car types, charging technologies, and customers' sentiments have changed during our observation period, and they might change even more dramatically in the future. It will, therefore, be interesting to see further studies on the matter covering the standardized roll-out. Public charging might become more important in order to convince those costumers who - until now have shied away from electric vehicles due to range anxiety. It might, however, also lose relevance when, e. g., future housing includes private charging facilities by default. The emergence of alternative fuels (e. g. hydrogen) might change the whole story entirely. 
Table 8

Results D - BEV registrations and Ø charging capacity (= abundance effect)

\begin{tabular}{|c|c|c|c|c|c|c|}
\hline \multirow[t]{2}{*}{$\begin{array}{l}\text { Dep. var.: } \\
\triangle B E V\end{array}$} & \multicolumn{2}{|c|}{$\begin{array}{l}\text { Dynamic fixed effects } \\
\text { (DFE) }\end{array}$} & \multicolumn{2}{|c|}{$\begin{array}{l}\text { Pooled mean group } \\
(\mathrm{PMG})\end{array}$} & \multicolumn{2}{|c|}{$\begin{array}{l}\text { Mean group } \\
(\mathrm{MG})\end{array}$} \\
\hline & $(1)$ & $(2)$ & $(3)$ & $(4)$ & $(5)$ & $(6)$ \\
\hline $\begin{array}{l}\text { Long-run } \\
\varnothing \text { charg. capacity }\left(C_{a}\right) \\
(=\text { abundance })\end{array}$ & $\begin{array}{l}0.16^{* * *} \\
(0.01)\end{array}$ & $\begin{array}{l}0.02^{*} \\
(0.01)\end{array}$ & $\begin{array}{l}0.13^{* * *} \\
(0.00)\end{array}$ & $\begin{array}{l}0.01^{* * *} \\
(0.00)\end{array}$ & $\begin{array}{l}0.65 \\
(0.43)\end{array}$ & $\begin{array}{l}0.03 \\
(0.13)\end{array}$ \\
\hline Error-correction term & $\begin{array}{l}-0.48^{* * *} \\
(0.01)\end{array}$ & $\begin{array}{l}-0.57^{* * *} \\
(0.01)\end{array}$ & $\begin{array}{l}-0.57^{* * *} \\
(0.01)\end{array}$ & $\begin{array}{l}-1.01^{* * *} \\
(0.01)\end{array}$ & $\begin{array}{l}-0.71^{* * *} \\
(0.01)\end{array}$ & $\begin{array}{l}-1.08^{* * *} \\
(0.01)\end{array}$ \\
\hline \multicolumn{7}{|l|}{ Short-run } \\
\hline l. $\triangle B E V$ & $\begin{array}{l}-0.24^{* * *} \\
(0.01)\end{array}$ & $\begin{array}{l}-0.20^{* * *} \\
(0.01)\end{array}$ & $\begin{array}{l}-0.25^{* * *} \\
(0.01)\end{array}$ & $\begin{array}{l}0.03^{* *} \\
(0.01)\end{array}$ & $\begin{array}{l}-0.16^{* * *} \\
(0.01)\end{array}$ & $\begin{array}{l}0.07^{* * *} \\
(0.01)\end{array}$ \\
\hline $12 . \Delta B E V$ & $\begin{array}{l}-0.07^{* * *} \\
(0.01)\end{array}$ & $\begin{array}{l}-0.06^{* * *} \\
(0.01)\end{array}$ & $\begin{array}{l}-0.14^{* * *} \\
(0.01)\end{array}$ & $\begin{array}{l}-0.00 \\
(0.01)\end{array}$ & $\begin{array}{l}-0.10^{* * * *} \\
(0.01)\end{array}$ & $\begin{array}{l}0.01 \\
(0.01)\end{array}$ \\
\hline$\Delta C_{a}$ & $\begin{array}{l}-0.02 \\
(0.01)\end{array}$ & $\begin{array}{l}0.01 \\
(0.01)\end{array}$ & $\begin{array}{l}0.07 \\
(0.18)\end{array}$ & $\begin{array}{l}0.15 \\
(0.15)\end{array}$ & $\begin{array}{l}-0.03 \\
(0.19)\end{array}$ & $\begin{array}{l}0.12 \\
(0.18)\end{array}$ \\
\hline 1. $\Delta C_{a}$ & $\begin{array}{l}-0.06^{* * *} \\
(0.01)\end{array}$ & $\begin{array}{l}-0.02^{*} \\
(0.01)\end{array}$ & $\begin{array}{l}0.07 \\
(0.16)\end{array}$ & $\begin{array}{l}-0.05 \\
(0.07)\end{array}$ & $\begin{array}{l}-0.02 \\
(0.14)\end{array}$ & $\begin{array}{l}-0.06 \\
(0.11)\end{array}$ \\
\hline $12 . \Delta C_{a}$ & $\begin{array}{l}-0.05^{* * *} \\
(0.01)\end{array}$ & $\begin{array}{l}-0.02 \\
(0.01)\end{array}$ & $\begin{array}{l}-0.31 \\
(0.30)\end{array}$ & $\begin{array}{l}-0.38^{*} \\
(0.19)\end{array}$ & $\begin{array}{l}-0.38 \\
(0.32)\end{array}$ & $\begin{array}{l}-0.38 \\
(0.20)\end{array}$ \\
\hline \multicolumn{7}{|l|}{ CS-means $\left(\overline{\boldsymbol{Z}}_{t}\right)$} \\
\hline$\overline{B E V}$ & - & $\begin{array}{l}0.82^{* * *} \\
(0.01)\end{array}$ & - & $\begin{array}{l}0.96 * * * \\
(0.04)\end{array}$ & - & $\begin{array}{l}0.95^{* * *} \\
(0.04)\end{array}$ \\
\hline 1. $\overline{B E V}$ & - & $\begin{array}{l}-0.14^{* * *} \\
(0.01)\end{array}$ & - & $\begin{array}{l}-0.02 \\
(0.02)\end{array}$ & - & $\begin{array}{l}0.01 \\
(0.02)\end{array}$ \\
\hline $12 . \overline{B E V}$ & - & $\begin{array}{l}-0.10^{* * *} \\
(0.01)\end{array}$ & - & $\begin{array}{l}0.04^{*} \\
(0.02)\end{array}$ & - & $\begin{array}{l}0.07^{* * *} \\
(0.02)\end{array}$ \\
\hline $13 . \overline{B E V}$ & - & $\begin{array}{l}-0.06^{* * *} \\
(0.01)\end{array}$ & - & $\begin{array}{l}0.01 \\
(0.02)\end{array}$ & - & $\begin{array}{l}0.03 \\
(0.02)\end{array}$ \\
\hline $14 . \overline{B E V}$ & - & $\begin{array}{l}-0.00 \\
(0.01)\end{array}$ & - & $\begin{array}{l}-0.00 \\
(0.02)\end{array}$ & - & $\begin{array}{l}-0.00 \\
(0.02)\end{array}$ \\
\hline$\overline{C_{a}}$ & - & $\begin{array}{l}0.02 \\
(0.02)\end{array}$ & - & $\begin{array}{l}-0.14 \\
(0.14)\end{array}$ & - & $\begin{array}{l}-0.14 \\
(0.14)\end{array}$ \\
\hline 1. $\overline{C_{a}}$ & - & $\begin{array}{l}-0.01 \\
(0.03)\end{array}$ & - & $\begin{array}{l}0.11 \\
(0.19)\end{array}$ & - & $\begin{array}{l}0.11 \\
(0.18)\end{array}$ \\
\hline $12 . \overline{C_{a}}$ & - & $\begin{array}{l}0.01 \\
(0.03)\end{array}$ & - & $\begin{array}{l}0.10 \\
(0.23)\end{array}$ & - & $\begin{array}{l}0.06 \\
(0.23)\end{array}$ \\
\hline $13 . \overline{C_{a}}$ & - & $\begin{array}{c}-0.02 \\
(0.03)\end{array}$ & - & $\begin{array}{l}-0.18 \\
(0.25)\end{array}$ & - & $\begin{array}{l}-0.16 \\
(0.25)\end{array}$ \\
\hline $14 . \overline{C_{a}}$ & - & $\begin{array}{l}0.02 \\
(0.02) \\
\end{array}$ & - & $\begin{array}{l}0.19 \\
(0.25)\end{array}$ & - & $\begin{array}{l}0.13 \\
(0.27) \\
\end{array}$ \\
\hline Constant & $\begin{array}{l}0.98^{* * *} \\
(0.07)\end{array}$ & $\begin{array}{c}-0.11 \\
(0.12)\end{array}$ & $\begin{array}{l}1.32^{* * *} \\
(0.09)\end{array}$ & $\begin{array}{c}-1.42 \\
(2.32) \\
\end{array}$ & $\begin{array}{l}2.41 \\
(2.68) \\
\end{array}$ & $\begin{array}{l}-0.12 \\
(3.54) \\
\end{array}$ \\
\hline Hausman test $p$-value & & 0.94 & & 0.89 & & - \\
\hline
\end{tabular}

Note: Standard errors in parentheses. Groups: 594, Obs.: 40,392. *** $p<0.001,{ }^{* *} p<0.01,{ }^{*} p<0.05$ 
Table 9

Results E - PHEV registrations and Ø charging capacity (= abundance effect)

\begin{tabular}{|c|c|c|c|c|c|c|}
\hline \multirow[t]{2}{*}{$\begin{array}{l}\text { Dep. var.: } \\
\triangle P H E V\end{array}$} & \multicolumn{2}{|c|}{$\begin{array}{l}\text { Dynamic fixed effects } \\
\text { (DFE) }\end{array}$} & \multicolumn{2}{|c|}{$\begin{array}{l}\text { Pooled mean group } \\
(\mathrm{PMG})\end{array}$} & \multicolumn{2}{|c|}{$\begin{array}{l}\text { Mean group } \\
(\mathrm{MG})\end{array}$} \\
\hline & $(1)$ & $(2)$ & $(3)$ & $(4)$ & $(5)$ & $(6)$ \\
\hline $\begin{array}{l}\text { Long-run coefficient } \\
\varnothing \text { charg. capacity }\left(C_{a}\right) \\
(=\text { abundance })\end{array}$ & $\begin{array}{l}0.20^{* * *} \\
(0.01)\end{array}$ & $\begin{array}{l}0.02^{* *} \\
(0.01)\end{array}$ & $\begin{array}{l}0.22^{* * *} \\
(0.00)\end{array}$ & $\begin{array}{l}0.01^{* * *} \\
(0.00)\end{array}$ & $\begin{array}{l}0.93 \\
(0.77)\end{array}$ & $\begin{array}{l}0.12 \\
(0.18)\end{array}$ \\
\hline Error-correction term & $\begin{array}{l}-0.42^{* * *} \\
(0.01)\end{array}$ & $\begin{array}{l}-0.62^{* * *} \\
(0.01)\end{array}$ & $\begin{array}{l}-0.41^{* * *} \\
(0.01)\end{array}$ & $\begin{array}{l}-0.99^{* * *} \\
(0.02)\end{array}$ & $\begin{array}{l}-0.55^{* * *} \\
(0.01)\end{array}$ & $\begin{array}{l}-1.08^{* * *} \\
(0.02)\end{array}$ \\
\hline \multicolumn{7}{|l|}{ Short-run coefficients } \\
\hline l. $\triangle P H E V$ & $\begin{array}{l}-0.28^{* * *} \\
(0.01)\end{array}$ & $\begin{array}{l}-0.16^{* * *} \\
(0.01)\end{array}$ & $\begin{array}{l}-0.34^{* * *} \\
(0.01)\end{array}$ & $\begin{array}{l}0.02 \\
(0.01)\end{array}$ & $\begin{array}{l}-0.25^{* * *} \\
(0.01)\end{array}$ & $\begin{array}{l}0.08^{* * *} \\
(0.01)\end{array}$ \\
\hline 12. $\triangle P H E V$ & $\begin{array}{l}-0.16^{* * *} \\
(0.01)\end{array}$ & $\begin{array}{l}-0.10^{* * *} \\
(0.01)\end{array}$ & $\begin{array}{l}-0.20^{* * * *} \\
(0.01)\end{array}$ & $\begin{array}{l}-0.01 \\
(0.01)\end{array}$ & $\begin{array}{l}-0.16^{* * *} \\
(0.01)\end{array}$ & $\begin{array}{l}0.01 \\
(0.01)\end{array}$ \\
\hline$\Delta C_{a}$ & $\begin{array}{l}-0.04^{* * *} \\
(0.01)\end{array}$ & $\begin{array}{l}-0.00 \\
(0.01)\end{array}$ & $\begin{array}{l}0.28 \\
(0.16)\end{array}$ & $\begin{array}{l}0.11 \\
(0.14)\end{array}$ & $\begin{array}{l}0.22 \\
(0.16)\end{array}$ & $\begin{array}{l}0.07 \\
(0.17)\end{array}$ \\
\hline 1. $\Delta C_{a}$ & $\begin{array}{l}-0.04^{* * *} \\
(0.01)\end{array}$ & $\begin{array}{l}-0.01 \\
(0.01)\end{array}$ & $\begin{array}{l}0.05 \\
(0.07)\end{array}$ & $\begin{array}{l}0.08 \\
(0.07)\end{array}$ & $\begin{array}{l}0.03 \\
(0.08)\end{array}$ & $\begin{array}{l}0.01 \\
(0.11)\end{array}$ \\
\hline $12 . \Delta C_{a}$ & $\begin{array}{l}-0.03^{* * *} \\
(0.01)\end{array}$ & $\begin{array}{l}-0.00 \\
(0.01)\end{array}$ & $\begin{array}{l}0.02 \\
(0.07)\end{array}$ & $\begin{array}{l}0.04 \\
(0.12)\end{array}$ & $\begin{array}{l}0.03 \\
(0.11)\end{array}$ & $\begin{array}{l}-0.01 \\
(0.12)\end{array}$ \\
\hline \multicolumn{7}{|l|}{ CS-means $\left(\overline{\boldsymbol{Z}}_{t}\right)$} \\
\hline$\overline{P H E V}$ & - & $\begin{array}{l}0.81 * * * \\
(0.01)\end{array}$ & - & $\begin{array}{l}0.93^{* * *} \\
(0.04)\end{array}$ & - & $\begin{array}{l}0.93^{* * *} \\
(0.04)\end{array}$ \\
\hline 1. $\overline{P H E V}$ & - & $\begin{array}{l}-0.15^{* * *} \\
(0.01)\end{array}$ & - & $\begin{array}{l}-0.02 \\
(0.03)\end{array}$ & - & $\begin{array}{l}0.00 \\
(0.03)\end{array}$ \\
\hline $12 . \overline{P H E V}$ & - & $\begin{array}{l}-0.04^{* *} \\
(0.01)\end{array}$ & - & $\begin{array}{l}0.05^{*} \\
(0.02)\end{array}$ & - & $\begin{array}{l}0.08^{* * *} \\
(0.02)\end{array}$ \\
\hline 13. $\overline{P H E V}$ & - & $\begin{array}{l}-0.07^{* * *} \\
(0.01)\end{array}$ & - & $\begin{array}{l}0.00 \\
(0.02)\end{array}$ & - & $\begin{array}{l}0.03 \\
(0.02)\end{array}$ \\
\hline $14 . \overline{P H E V}$ & - & $\begin{array}{l}0.00 \\
(0.01)\end{array}$ & - & $\begin{array}{l}0.01 \\
(0.02)\end{array}$ & - & $\begin{array}{l}-0.00 \\
(0.02)\end{array}$ \\
\hline$\overline{C_{a}}$ & - & $\begin{array}{l}-0.01 \\
(0.02)\end{array}$ & - & $\begin{array}{l}0.08 \\
(0.16)\end{array}$ & - & $\begin{array}{l}0.01 \\
(0.16)\end{array}$ \\
\hline $1 . \overline{C_{a}}$ & - & $\begin{array}{l}0.01 \\
(0.02)\end{array}$ & - & $\begin{array}{l}0.14 \\
(0.30)\end{array}$ & - & $\begin{array}{l}0.18 \\
(0.31)\end{array}$ \\
\hline $12 . \overline{C_{a}}$ & - & $\begin{array}{l}-0.01 \\
(0.02)\end{array}$ & - & $\begin{array}{l}-0.33 \\
(0.33)\end{array}$ & - & $\begin{array}{l}-0.43 \\
(0.34)\end{array}$ \\
\hline $13 . \overline{C_{a}}$ & - & $\begin{array}{l}0.01 \\
(0.02)\end{array}$ & - & $\begin{array}{l}0.29 \\
(0.28)\end{array}$ & - & $\begin{array}{l}0.21 \\
(0.27)\end{array}$ \\
\hline $14 . \overline{C_{a}}$ & - & $\begin{array}{l}0.02 \\
(0.02) \\
\end{array}$ & - & $\begin{array}{c}-0.02 \\
(0.36) \\
\end{array}$ & - & $\begin{array}{l}-0.06 \\
(0.37) \\
\end{array}$ \\
\hline Constant & $\begin{array}{l}0.50 * * * \\
(0.04)\end{array}$ & $\begin{array}{c}-0.18^{*} \\
(0.08)\end{array}$ & $\begin{array}{l}0.53^{* * *} \\
(0.04)\end{array}$ & $\begin{array}{l}-3.51 \\
(5.84) \\
\end{array}$ & $\begin{array}{l}0.86 \\
(2.68) \\
\end{array}$ & $\begin{array}{l}1.14 \\
(6.54) \\
\end{array}$ \\
\hline Hausman test ( $p$-value) & & 0.55 & & 0.52 & & - \\
\hline
\end{tabular}

Note: Standard errors in parentheses. Groups: 594, Obs.: 40,392. *** $p<0.001,{ }^{* *} p<0.01,{ }^{*} p<0.05$ 


\section{References}

Adjemian, M. K., Cynthia Lin, C. Y. and Williams, J. (2010). Estimating spatial interdependence in automobile type choice with survey data. Transportation Research Part A: Policy and Practice, 44 (9), 661-675.

Axsen, J. and KurAni, K. S. (2011). Interpersonal influence in the early plug-in hybrid market: Observing social interactions with an exploratory multi-method approach. Transportation Research Part D: Transport and Environment, 16 (2), 150-159.

— and - (2013). Hybrid, plug-in hybrid, or electric - What do car buyers want? Energy Policy, 61, 532-543.

-, Langman, B. and Goldberg, S. (2017). Confusion of innovations: Mainstream consumer perceptions and misperceptions of electric-drive vehicles and charging programs in Canada. Energy Research \&5 Social Science, 27, 163-173.

-, Mountain, D. C. and JacCard, M. (2009). Combining stated and revealed choice research to simulate the neighbor effect: The case of hybrid-electric vehicles. Resource and Energy Economics, 31 (3), 221-238.

Azadfar, E., Sreeram, V. and Harries, D. (2015). The investigation of the major factors influencing plug-in electric vehicle driving patterns and charging behaviour. Renewable and Sustainable Energy Reviews, 42, 1065-1076.

Bailey, J., Miele, A. and Axsen, J. (2015). Is awareness of public charging associated with consumer interest in plug-in electric vehicles? Transportation Research Part D: Transport and Environment, 36, 1-9.

Baltagi, B. H., Griffin, J. M. and Xiong, W. (2000). To pool or not to pool homogeneous versus heterogeneous estimators applied to cigarette demand. Review of Economics and Statistics, 82 (1), 117-126.

Bansal, P., Kockelman, K. M. and Wang, Y. (2015). Hybrid Electric Vehicle Ownership and Fuel Economy Across Texas. Transportation Research Record: Journal of the Transportation Research Board, 2495, 53-64.

BAum, C. (2018). KPSS: Stata module to compute Kwiatkowski-Phillips-Schmidt-Shin test for stationarity. Statistical Software Components, Boston College Department of Economics. 
Blackburne III, E. F. and Frank, M. W. (2007). Estimation of nonstationary heterogeneous panels. The Stata Journal, 7 (2), 197-208.

Bonham, C. S. and Cohen, R. H. (2001). To aggregate, pool, or neither: Testing the rational - expectations hypothesis using survey data. Journal of Business 85 Economic Statistics, 19 (3), 278-291.

Brady, J. and O'Mahony, M. (2011). Travel to work in Dublin. The potential impacts of electric vehicles on climate change and urban air quality. Transportation Research Part D: Transport and Environment, 16 (2), 188-193.

Cavallaro, F., Danielis, R., Nocera, S. and Rotaris, L. (2018). Should BEVs be subsidized or taxed? A European perspective based on the economic value of $\mathrm{CO} 2$ emissions. Transportation Research Part D: Transport and Environment, 64, 70-89.

Chen, T. D., Wang, Y. and Kockelman, K. M. (2015). Where are the electric vehicles? A spatial model for vehicle-choice count data. Journal of Transport Geography, 43, 181-188.

Chudik, A., Mohaddes, K., Pesaran, M. H. and Raissi, M. (2017). Is there a debt-threshold effect on output growth? Review of Economics and Statistics, 99 (1), $135-150$.

— and Pesaran, M. H. (2015). Common correlated effects estimation of heterogeneous dynamic panel data models with weakly exogenous regressors. Journal of Econometrics, 188 (2), 393-420.

Coffman, M., Bernstein, P. and Wee, S. (2017). Electric vehicles revisited: A review of factors that affect adoption. Transport Reviews, 37 (1), 79-93.

De Hoyos, R. E. and Sarafidis, V. (2006). Testing for cross-sectional dependence in panel-data models. Stata Journal, 6 (4), 482-496.

Dimatulac, T. and MaOH, H. (2017). The spatial distribution of hybrid electric vehicles in a sprawled mid-size Canadian city: Evidence from Windsor, Canada. Journal of Transport Geography, 60, 59-67.

Engle, R. F. and Granger, C. W. (1987). Co-Integration and Error Correction: Representation, Estimation, and Testing. Econometrica: Journal of the Econometric Society, 55 (2), 251-276. 
EU Commission (2018). Transport in the European Union - Current Trends and Issues. https://ec.europa.eu/transport/sites/transport/files/ 2018-transport-in-the-eu-current-trends-and-issues.pdf .

EU Parliament (2018). Directive 2014/94/EU of the European Parliament and of the Council - of 22 October 2014 - on the deployment of alternative fuels infrastructure. https://eur-lex.europa.eu/legal-content/EN/TXT/PDF/?uri= CELEX : 32014L0094\&f rom $=$ en.

European Environment Agency (2016). Electric vehicles in Europe. http:// bookshop. europa .eu/uri?target=EUB : NOTICE: THAL16019: EN : HTML.

European Environment Agency (2018). Electric vehicles as a proportion of the total fleet - Indicator Assessment / Data and Maps. https://www.eea.europa. eu/data-and-maps/indicators/proportion-of-vehicle-fleet-meeting-4/ assessment -2 .

Federal Motor Transport Authority (2018). Mtl. Neuzulassungen von Personenkraftwagen/M1-Fahrzeugen und leichten Nutzfahrzeugen kleiner/gleich 3.500 kg nach 5 stelliger Postleitzahl und ausgewählten Kraftstoffarten bzw. Energiequellen rückwirkend für die Jahre 2009 bis 2016. Flensburg: Federal Motor Transport Authority.

Federal Motor Transport Authority (2019). Jahresbilanz der Neuzulassungen 2017. https://www.kba.de/DE/Statistik/Fahrzeuge/Neuzulassungen/ Ueberblick_archiv/2017_neuzulassungen_node.html.

Federal Network Agency (2019). Ladesäulenliste, Mai, 2019. https://www. bundesnetzagentur.de/DE/Sachgebiete/ElektrizitaetundGas/Unternehmen_ Institutionen/HandelundVertrieb/Ladesaeulenkarte/Ladesaeulenkarte_node. html.

Fetene, G. M., Hirte, G., Kaplan, S., Prato, C. G. and Tscharaktschiew, S. (2016). The economics of workplace charging. Transportation Research Part B: Methodological, 88, 93-118.

Figenbaum, E. (2017). Perspectives on Norway's supercharged electric vehicle policy. Environmental Innovation and Societal Transitions, 25, 14-34. 
— and Kolbenstvedt, M. (2016). Learning from Norwegian Battery Electric and Plug-in Hybrid Vehicle users - Results from a survey of vehicle owners. Tech. Rep. 1492/2016, Institute of Transport Economics Norwegian Centre for Transport Research.

Franke, T. and Krems, J. F. (2013). What drives range preferences in electric vehicle users? Transport Policy, 30, 56-62.

Gallagher, K. S. and MuehlegGer, E. (2011). Giving green to get green? Incentives and consumer adoption of hybrid vehicle technology. Journal of Environmental Economics and Management, 61 (1), 1-15.

Gass, V., Schmidt, J. and Schmid, E. (2014). Analysis of alternative policy instruments to promote electric vehicles in Austria. Renewable Energy, 61, 96-101.

German Environment Agency (2017). Indicator: Greenhouse gas emissions. http: //www. umweltbundesamt.de/en/indicator-greenhouse-gas-emissions.

German Government (2018). Koalitionsvertrag zwischen CDU, CSU und SPD. https://www. bundesregierung.de/resource/blob/975226/847984/ 5b8bc23590d4cb2892b31c987ad672b7/2018-03-14-koalitionsvertrag-data. pdf?download $=1$.

Gnann, T., Funke, S., Jakobsson, N., Plötz, P., Sprei, F. and Bennehag, A. (2018). Fast charging infrastructure for electric vehicles: Today's situation and future needs. Transportation Research Part D: Transport and Environment, 62, 314-329.

— and PlÖTZ, P. (2015). A review of combined models for market diffusion of alternative fuel vehicles and their refueling infrastructure. Renewable and Sustainable Energy Reviews, 47, 783-793.

Greene, W. H. (2003). Econometric Analysis. Pearson Education.

Hackbarth, A. and Madlener, R. (2013). Consumer preferences for alternative fuel vehicles: A discrete choice analysis. Transportation Research Part D: Transport and Environment, 25, 5-17.

HADRI, K. (2000). Testing for stationarity in heterogeneous panel data. The Econometrics Journal, 3 (2), 148-161. 
Hardman, S., Chandan, A., Tal, G. and Turrentine, T. (2017). The effectiveness of financial purchase incentives for battery electric vehicles - A review of the evidence. Renewable and Sustainable Energy Reviews, 80, 1100-1111.

-, Jenn, A., Tal, G., Axsen, J., Beard, G., Daina, N., Figenbaum, E., Jakobsson, N., Jochem, P., Kinnear, N., Plötz, P., Pontes, J., Refa, N., Sprei, F., Turrentine, T. and Witkamp, B. (2018). A review of consumer preferences of and interactions with electric vehicle charging infrastructure. Transportation Research Part D: Transport and Environment, 62, 508-523.

Hensher, D. A. (2010). Hypothetical bias, choice experiments and willingness to pay. Transportation Research Part B: Methodological, 44 (6), 735-752.

Herzer, D. (2019). The long-run effect of aid on health: evidence from panel cointegration analysis. Applied Economics, 51 (12), 1319-1338.

Hidrue, M. K., Parsons, G. R., Kempton, W. and Gardner, M. P. (2011). Willingness to pay for electric vehicles and their attributes. Resource and Energy Economics, 33 (3), 686-705.

ICCT (2018). The European vehicle market statistics pocketbook. https: //www.theicct.org/sites/default/files/publications/ICCT_Pocketbook_ 2018_Final_20181205.pdf.

JAVID, R. J. and NejAT, A. (2017). A comprehensive model of regional electric vehicle adoption and penetration. Transport Policy, 54, 30-42.

KAO, C. (1999). Spurious regression and residual-based tests for cointegration in panel data. Journal of econometrics, 90 (1), 1-44.

Kinm, A. and Trommer, S. (2014). The new car market for electric vehicles and the potential for fuel substitution. Energy Policy, 73, 147-157.

Lane, B. and Potter, S. (2007). The adoption of cleaner vehicles in the UK: Exploring the consumer attitude-action gap. Journal of Cleaner Production, 15 (11), 1085-1092.

Levin, A., Lin, C.-F. and Chu, C.-S. J. (2002). Unit root tests in panel data: Asymptotic and finite-sample properties. Journal of Econometrics, 108 (1), 1-24. 
Liao, F., Molin, E. and van Wee, B. (2017). Consumer preferences for electric vehicles: A literature review. Transport Reviews, 37 (3), 252-275.

Liu, X., Roberts, M. C. and Sioshansi, R. (2017). Spatial effects on hybrid electric vehicle adoption. Transportation Research Part D: Transport and Environment, 52, $85-97$.

LütkePohl, H. (2007). General-to-specific or specific-to-general modelling? An opinion on current econometric terminology. Journal of Econometrics, 136 (1), 319-324.

Morrissey, P., Weldon, P. and O’Mahony, M. (2016). Future standard and fast charging infrastructure planning: An analysis of electric vehicle charging behaviour. Energy Policy, 89, 257-270.

Musti, S. and Kockelman, K. M. (2011). Evolution of the household vehicle fleet: Anticipating fleet composition, PHEV adoption and GHG emissions in Austin, Texas. Transportation Research Part A: Policy and Practice, 45 (8), 707-720.

Neaimeh, M., Salisbury, S. D., Hill, G. A., Blythe, P. T., Scoffield, D. R. and Francfort, J. E. (2017). Analysing the usage and evidencing the importance of fast chargers for the adoption of battery electric vehicles. Energy Policy, 108, 474-486.

Nicholas, M., Tal, G. and Ji, W. (2017). Lessons from In-Use Fast Charging Data: Why Are Drivers Staying Close to Home? Tech. rep., Institute of Transportation Studies.

Pedroni, P. (1999). Critical values for cointegration tests in heterogeneous panels with multiple regressors. Oxford Bulletin of Economics and statistics, 61 (S1), 653-670.

- (2004). Panel cointegration: asymptotic and finite sample properties of pooled time series tests with an application to the PPP hypothesis. Econometric Theory, 20 (3), $597-625$.

Pesaran, M. H. (2004). General diagnostic tests for cross section dependence in panels. CESifo working papers, 1229.

- (2012). On the interpretation of panel unit root tests. Economics Letters, 116 (3), $545-546$. 
—, Shin, Y. and Smith, R. P. (1999). Pooled Mean Group Estimation of Dynamic Heterogeneous Panels. Journal of the American Statistical Association, 94 (446), 621634.

— and Smith, R. (1995). Estimating long-run relationships from dynamic heterogeneous panels. Journal of Econometrics, 68 (1), 79-113.

Plötz, P., Schneider, U., Globisch, J. and Dütschke, E. (2014). Who will buy electric vehicles? Identifying early adopters in Germany. Transportation Research Part A: Policy and Practice, 67, 96-109.

Potoglou, D. and Kanaroglou, P. S. (2007). Household demand and willingness to pay for clean vehicles. Transportation Research Part D: Transport and Environment, 12 (4), 264-274.

Rasouli, S. and Timmermans, H. (2016). Influence of social networks on latent choice of electric cars: A mixed logit specification using experimental design data. Networks and Spatial Economics, 16 (1), 99-130.

Requia, W. J., Mohamed, M., Higgins, C. D., Arain, A. and Ferguson, M. (2018). How clean are electric vehicles? Evidence-based review of the effects of electric mobility on air pollutants, greenhouse gas emissions and human health. Atmospheric Environment, 185, 64-77.

Rezvani, Z., Jansson, J. and Bodin, J. (2015). Advances in consumer electric vehicle adoption research: A review and research agenda. Transportation Research Part D: Transport and Environment, 34, 122-136.

Schmelzer, S. and Miess, M. (2015). The Economic Costs of Electric Vehicles. Tech. rep., DEFINE Working Papers.

Sierzchula, W., Bakker, S., Maft, K. and van Wee, B. (2014). The influence of financial incentives and other socio-economic factors on electric vehicle adoption. Energy Policy, 68, 183-194.

Stock, J. H. (1987). Asymptotic Properties of Least Squares Estimators of Cointegrating Vectors. Econometrica, 55 (5), 1035. 
Tscharaktschiew, S. (2015). How much should gasoline be taxed when electric vehicles conquer the market? An analysis of the mismatch between efficient and existing gasoline taxes under emerging electric mobility. Transportation Research Part D: Transport and Environment, 39, 89-113.

Westerlund, J. (2005). New simple tests for panel cointegration. Econometric Reviews, 24 (3), 297-316.

YAnG, Y., YaO, E., YAng, Z. and Zhang, R. (2016). Modeling the charging and route choice behavior of BEV drivers. Transportation Research Part C: Emerging Technologies, 65, 190-204. 
Table A1

Results $F-B E V$ registrations and number of charging stations (= visibility effect)

\begin{tabular}{|c|c|c|c|c|c|c|}
\hline \multirow[t]{2}{*}{$\begin{array}{l}\text { Dep. var.: } \\
\triangle B E V\end{array}$} & \multicolumn{2}{|c|}{$\begin{array}{l}\text { Dynamic fixed effects } \\
\text { (DFE) }\end{array}$} & \multicolumn{2}{|c|}{$\begin{array}{l}\text { Pooled mean group } \\
(\mathrm{PMG})\end{array}$} & \multicolumn{2}{|c|}{$\begin{array}{l}\text { Mean group } \\
(\mathrm{MG})\end{array}$} \\
\hline & (1) & $(2)$ & (3) & $(4)$ & (5) & (6) \\
\hline \multicolumn{7}{|l|}{ Long-run } \\
\hline $\begin{array}{l}\text { Charging stations }\left(C_{v}\right) \\
(=\text { visibility })\end{array}$ & $\begin{array}{l}0.24^{* * *} \\
(0.01)\end{array}$ & $\begin{array}{l}0.02 \\
(0.01)\end{array}$ & $\begin{array}{l}0.39 * * * \\
(0.01)\end{array}$ & $\begin{array}{l}-0.02 \\
(0.01)\end{array}$ & $\begin{array}{l}1.25^{* * *} \\
(0.20)\end{array}$ & $\begin{array}{l}0.10 \\
(0.10)\end{array}$ \\
\hline Error-correction term & $\begin{array}{l}-0.48^{* * *} \\
(0.01)\end{array}$ & $\begin{array}{l}-0.57^{* * *} \\
(0.01)\end{array}$ & $\begin{array}{l}-0.67^{* * *} \\
(0.01)\end{array}$ & $\begin{array}{l}-1.06^{* * *} \\
(0.01)\end{array}$ & $\begin{array}{l}-0.82^{* * *} \\
(0.01)\end{array}$ & $\begin{array}{l}-1.11^{* * *} \\
(0.01)\end{array}$ \\
\hline \multicolumn{7}{|l|}{ Short-run } \\
\hline 1. $\triangle B E V$ & $\begin{array}{l}-0.24^{* * *} \\
(0.01)\end{array}$ & $\begin{array}{l}-0.20^{* * *} \\
(0.01)\end{array}$ & $\begin{array}{l}-0.19^{* * *} \\
(0.01)\end{array}$ & $\begin{array}{l}0.05^{* * *} \\
(0.01)\end{array}$ & $\begin{array}{l}-0.09^{* * *} \\
(0.01)\end{array}$ & $\begin{array}{l}0.09 * * * \\
(0.01)\end{array}$ \\
\hline $12 . \Delta B E V$ & $\begin{array}{l}-0.07^{* * *} \\
(0.01)\end{array}$ & $\begin{array}{l}-0.06^{* * *} \\
(0.01)\end{array}$ & $\begin{array}{l}-0.11^{* * *} \\
(0.01)\end{array}$ & $\begin{array}{l}0.02^{*} \\
(0.01)\end{array}$ & $\begin{array}{l}-0.06^{* * *} \\
(0.01)\end{array}$ & $\begin{array}{l}0.03^{* * *} \\
(0.01)\end{array}$ \\
\hline$\Delta C_{v}$ & $\begin{array}{l}0.11^{* *} \\
(0.04)\end{array}$ & $\begin{array}{l}0.03 \\
(0.04)\end{array}$ & $\begin{array}{l}0.27^{*} \\
(0.11)\end{array}$ & $\begin{array}{l}0.17 \\
(0.10)\end{array}$ & $\begin{array}{l}-0.43^{* *} \\
(0.14)\end{array}$ & $\begin{array}{l}0.03 \\
(0.13)\end{array}$ \\
\hline l. $\Delta C_{v}$ & $\begin{array}{l}-0.01 \\
(0.04)\end{array}$ & $\begin{array}{l}-0.06 \\
(0.04)\end{array}$ & $\begin{array}{l}0.32 \\
(0.19)\end{array}$ & $\begin{array}{l}-0.04 \\
(0.13)\end{array}$ & $\begin{array}{l}-0.30 \\
(0.17)\end{array}$ & $\begin{array}{l}-0.14 \\
(0.18)\end{array}$ \\
\hline $12 . \Delta C_{v}$ & $\begin{array}{l}0.04 \\
(0.04)\end{array}$ & $\begin{array}{l}0.02 \\
(0.04)\end{array}$ & $\begin{array}{l}0.44 \\
(0.23)\end{array}$ & $\begin{array}{l}0.33^{*} \\
(0.13)\end{array}$ & $\begin{array}{l}-0.10 \\
(0.22)\end{array}$ & $\begin{array}{l}0.25 \\
(0.18)\end{array}$ \\
\hline \multicolumn{7}{|l|}{ CS-means $\left(\overline{\boldsymbol{Z}}_{t}\right)$} \\
\hline$\overline{B E V}$ & - & $\begin{array}{l}0.82^{* * *} \\
(0.01)\end{array}$ & - & $\begin{array}{l}0.96^{* * *} \\
(0.04)\end{array}$ & - & $\begin{array}{l}0.96^{* * *} \\
(0.04)\end{array}$ \\
\hline l. $\overline{B E V}$ & - & $\begin{array}{l}-0.15^{* * *} \\
(0.01)\end{array}$ & - & $\begin{array}{l}0.01 \\
(0.02)\end{array}$ & - & $\begin{array}{l}0.03 \\
(0.02)\end{array}$ \\
\hline $12 . \overline{B E V}$ & - & $\begin{array}{l}-0.10^{* * *} \\
(0.01)\end{array}$ & - & $\begin{array}{l}0.05^{* *} \\
(0.02)\end{array}$ & - & $\begin{array}{l}0.06^{* * *} \\
(0.02)\end{array}$ \\
\hline $13 . \overline{B E V}$ & - & $\begin{array}{l}-0.06^{* * *} \\
(0.01)\end{array}$ & - & $\begin{array}{l}0.02 \\
(0.02)\end{array}$ & - & $\begin{array}{l}0.03 \\
(0.02)\end{array}$ \\
\hline $14 . \overline{B E V}$ & - & $\begin{array}{l}-0.01 \\
(0.01)\end{array}$ & - & $\begin{array}{l}-0.00 \\
(0.02)\end{array}$ & - & $\begin{array}{l}-0.00 \\
(0.02)\end{array}$ \\
\hline$\overline{C_{v}}$ & - & $\begin{array}{l}1.84^{*} \\
(0.75)\end{array}$ & - & $\begin{array}{l}0.92 \\
(1.83)\end{array}$ & - & $\begin{array}{l}0.94 \\
(1.85)\end{array}$ \\
\hline $1 . \overline{C_{v}}$ & - & $\begin{array}{l}-0.13 \\
(1.14)\end{array}$ & - & $\begin{array}{l}-0.47 \\
(2.33)\end{array}$ & - & $\begin{array}{l}-0.10 \\
(2.30)\end{array}$ \\
\hline $12 . \overline{C_{v}}$ & - & $\begin{array}{l}-2.04 \\
(1.22)\end{array}$ & - & $\begin{array}{l}-1.17 \\
(2.63)\end{array}$ & - & $\begin{array}{l}-1.48 \\
(2.58)\end{array}$ \\
\hline $13 . \overline{C_{v}}$ & - & $\begin{array}{l}1.56 \\
(1.26)\end{array}$ & - & $\begin{array}{l}1.29 \\
(2.93)\end{array}$ & - & $\begin{array}{l}1.19 \\
(3.07)\end{array}$ \\
\hline $14 . \overline{C_{v}}$ & - & $\begin{array}{l}-0.93 \\
(0.84)\end{array}$ & - & $\begin{array}{l}1.28 \\
(2.17)\end{array}$ & - & $\begin{array}{l}0.71 \\
(2.21)\end{array}$ \\
\hline Constant & $\begin{array}{l}1.19^{* * *} \\
(0.06)\end{array}$ & $\begin{array}{l}0.06 \\
(0.06)\end{array}$ & $\begin{array}{l}1.14^{* * *} \\
(0.11)\end{array}$ & $\begin{array}{l}-0.08 \\
(0.09)\end{array}$ & $\begin{array}{l}0.75^{* * *} \\
(0.19)\end{array}$ & $\begin{array}{l}-0.11 \\
(0.13)\end{array}$ \\
\hline Hausman test $p$-value & & 0.38 & & 0.22 & & - \\
\hline
\end{tabular}

Note: Standard errors in parentheses. Groups: 594, Obs.: 40,392. *** $p<0.001,{ }^{* *} p<0.01,{ }^{*} p<0.05$ 
Table A2

Results $G-$ PHEV registrations and number of charging stations (= visibility effect)

\begin{tabular}{|c|c|c|c|c|c|c|}
\hline \multirow[t]{2}{*}{$\begin{array}{l}\text { Dep. var.: } \\
\triangle P H E V\end{array}$} & \multicolumn{2}{|c|}{$\begin{array}{l}\text { Dynamic fixed effects } \\
\text { (DFE) }\end{array}$} & \multicolumn{2}{|c|}{$\begin{array}{l}\text { Pooled mean group } \\
(\mathrm{PMG})\end{array}$} & \multicolumn{2}{|c|}{$\begin{array}{l}\text { Mean group } \\
(\mathrm{MG})\end{array}$} \\
\hline & (1) & $(2)$ & (3) & $(4)$ & (5) & (6) \\
\hline $\begin{array}{l}\text { Long-run coefficient } \\
\text { Charging stations }\left(C_{v}\right) \\
(=\text { visibility })\end{array}$ & $\begin{array}{l}0.30 * * * \\
(0.01)\end{array}$ & $\begin{array}{l}0.02^{*} \\
(0.01)\end{array}$ & $\begin{array}{l}0.52^{* * *} \\
(0.01)\end{array}$ & $\begin{array}{l}-0.02 \\
(0.01)\end{array}$ & $\begin{array}{l}1.27^{* *} \\
(0.48)\end{array}$ & $\begin{array}{l}0.03 \\
(0.10)\end{array}$ \\
\hline Error-correction term & $\begin{array}{l}-0.43^{* * *} \\
(0.01)\end{array}$ & $\begin{array}{l}-0.62^{* * *} \\
(0.01)\end{array}$ & $\begin{array}{l}-0.50^{* * *} \\
(0.01)\end{array}$ & $\begin{array}{l}-1.03^{* * *} \\
(0.02)\end{array}$ & $\begin{array}{l}-0.69^{* * *} \\
(0.02)\end{array}$ & $\begin{array}{l}-1.12^{* * *} \\
(0.02)\end{array}$ \\
\hline \multicolumn{7}{|l|}{ Short-run coefficients } \\
\hline 1. $\triangle P H E V$ & $\begin{array}{l}-0.27^{* * *} \\
(0.01)\end{array}$ & $\begin{array}{l}-0.16^{* * *} \\
(0.01)\end{array}$ & $\begin{array}{l}-0.27^{* * *} \\
(0.01)\end{array}$ & $\begin{array}{l}0.06^{* * *} \\
(0.01)\end{array}$ & $\begin{array}{l}-0.16^{* * *} \\
(0.01)\end{array}$ & $\begin{array}{l}0.11^{* * *} \\
(0.01)\end{array}$ \\
\hline 12. $\triangle P H E V$ & $\begin{array}{l}-0.15^{* * *} \\
(0.01)\end{array}$ & $\begin{array}{l}-0.09^{* * *} \\
(0.01)\end{array}$ & $\begin{array}{l}-0.17^{* * *} \\
(0.01)\end{array}$ & $\begin{array}{l}0.00 \\
(0.01)\end{array}$ & $\begin{array}{l}-0.11^{* * *} \\
(0.01)\end{array}$ & $\begin{array}{l}0.02^{* *} \\
(0.01)\end{array}$ \\
\hline$\Delta C_{v}$ & $\begin{array}{l}0.05^{*} \\
(0.03)\end{array}$ & $\begin{array}{l}-0.00 \\
(0.03)\end{array}$ & $\begin{array}{l}0.28^{* *} \\
(0.09)\end{array}$ & $\begin{array}{l}0.07 \\
(0.12)\end{array}$ & $\begin{array}{l}-0.43^{* * *} \\
(0.11)\end{array}$ & $\begin{array}{l}0.02 \\
(0.13)\end{array}$ \\
\hline 1. $\Delta C_{v}$ & $\begin{array}{l}0.05 \\
(0.03)\end{array}$ & $\begin{array}{l}0.02 \\
(0.03)\end{array}$ & $\begin{array}{l}0.23^{*} \\
(0.09)\end{array}$ & $\begin{array}{l}0.20 \\
(0.15)\end{array}$ & $\begin{array}{l}-0.38^{* * *} \\
(0.10)\end{array}$ & $\begin{array}{l}0.17 \\
(0.16)\end{array}$ \\
\hline $12 . \Delta C_{v}$ & $\begin{array}{l}0.00 \\
(0.03)\end{array}$ & $\begin{array}{l}-0.00 \\
(0.03)\end{array}$ & $\begin{array}{l}0.21^{*} \\
(0.08)\end{array}$ & $\begin{array}{l}0.11 \\
(0.15)\end{array}$ & $\begin{array}{l}-0.33^{* * *} \\
(0.10)\end{array}$ & $\begin{array}{l}0.12 \\
(0.16)\end{array}$ \\
\hline \multicolumn{7}{|l|}{ CS-means $\left(\overline{\boldsymbol{Z}}_{t}\right)$} \\
\hline$\overline{P H E V}$ & - & $\begin{array}{l}0.81^{* * *} \\
(0.01)\end{array}$ & - & $\begin{array}{l}0.92^{* * *} \\
(0.04)\end{array}$ & - & $\begin{array}{l}0.92^{* * *} \\
(0.04)\end{array}$ \\
\hline 1. $\overline{P H E V}$ & - & $\begin{array}{l}-0.15^{* * *} \\
(0.01)\end{array}$ & - & $\begin{array}{l}-0.01 \\
(0.03)\end{array}$ & - & $\begin{array}{l}0.02 \\
(0.03)\end{array}$ \\
\hline $12 . \overline{P H E V}$ & - & $\begin{array}{l}-0.04^{* * *} \\
(0.01)\end{array}$ & - & $\begin{array}{l}0.04 \\
(0.02)\end{array}$ & - & $\begin{array}{l}0.06^{* *} \\
(0.02)\end{array}$ \\
\hline $13 . \overline{P H E V}$ & - & $\begin{array}{l}-0.08^{* * *} \\
(0.01)\end{array}$ & - & $\begin{array}{l}0.02 \\
(0.02)\end{array}$ & - & $\begin{array}{l}0.04 \\
(0.02)\end{array}$ \\
\hline $14 . \overline{P H E V}$ & - & $\begin{array}{l}-0.01 \\
(0.01)\end{array}$ & - & $\begin{array}{l}-0.01 \\
(0.02)\end{array}$ & - & $\begin{array}{l}-0.02 \\
(0.02)\end{array}$ \\
\hline$\overline{C_{v}}$ & - & $\begin{array}{l}1.28^{*} \\
(0.51)\end{array}$ & - & $\begin{array}{l}-2.88 \\
(2.02)\end{array}$ & - & $\begin{array}{l}-3.18 \\
(2.05)\end{array}$ \\
\hline $1 . \overline{C_{v}}$ & - & $\begin{array}{c}-0.77 \\
(0.77)\end{array}$ & - & $\begin{array}{l}2.67 \\
(2.83)\end{array}$ & - & $\begin{array}{l}2.62 \\
(2.76)\end{array}$ \\
\hline $12 . \overline{C_{v}}$ & - & $\begin{array}{l}0.45 \\
(0.83)\end{array}$ & - & $\begin{array}{l}2.62 \\
(3.39)\end{array}$ & - & $\begin{array}{l}2.31 \\
(3.30)\end{array}$ \\
\hline $13 . \overline{C_{v}}$ & - & $\begin{array}{l}-0.37 \\
(0.85)\end{array}$ & - & $\begin{array}{l}-0.74 \\
(3.07)\end{array}$ & - & $\begin{array}{l}-1.38 \\
(3.07)\end{array}$ \\
\hline $14 . \overline{C_{v}}$ & - & $\begin{array}{l}-0.18 \\
(0.57)\end{array}$ & - & $\begin{array}{l}0.52 \\
(2.01)\end{array}$ & - & $\begin{array}{l}0.23 \\
(2.19)\end{array}$ \\
\hline Constant & $\begin{array}{l}0.77^{* * *} \\
(0.04)\end{array}$ & $\begin{array}{l}0.01 \\
(0.04)\end{array}$ & $\begin{array}{l}0.48^{* * *} \\
(0.06)\end{array}$ & $\begin{array}{l}-0.14 \\
(0.11)\end{array}$ & $\begin{array}{l}-0.20 \\
(0.15)\end{array}$ & $\begin{array}{l}-0.14 \\
(0.23)\end{array}$ \\
\hline Hausman test $p$-value & & 0.95 & & 0.64 & & - \\
\hline
\end{tabular}

Note: Standard errors in parentheses. Groups: 594, Obs.: 40,392. *** $p<0.001,{ }^{* *} p<0.01,{ }^{*} p<0.05$ 
Table A3

Results $H-B E V$ registrations and overall charging capacity (= capacity effect)

\begin{tabular}{|c|c|c|c|c|c|c|}
\hline \multirow[t]{2}{*}{$\begin{array}{l}\text { Dep. var.: } \\
\triangle B E V\end{array}$} & \multicolumn{2}{|c|}{$\begin{array}{l}\text { Dynamic fixed effects } \\
\text { (DFE) }\end{array}$} & \multicolumn{2}{|c|}{$\begin{array}{l}\text { Pooled mean group } \\
\text { (PMG) }\end{array}$} & \multicolumn{2}{|c|}{$\begin{array}{l}\text { Mean group } \\
(\mathrm{MG})\end{array}$} \\
\hline & $(1)$ & $(2)$ & (3) & $(4)$ & $(5)$ & (6) \\
\hline \multicolumn{7}{|l|}{ Long-run } \\
\hline $\begin{array}{l}\sum_{(=\text {capacity })} \text { charg. capacity }\left(C_{c}\right) \\
\text { capity }\end{array}$ & $\begin{array}{l}0.01^{* * *} \\
(0.00)\end{array}$ & $\begin{array}{l}0.00 \\
(0.00)\end{array}$ & $\begin{array}{l}0.01^{* * *} \\
(0.00)\end{array}$ & $\begin{array}{l}-0.00 \\
(0.00)\end{array}$ & $\begin{array}{l}0.10^{* *} \\
(0.04)\end{array}$ & $\begin{array}{l}0.02 \\
(0.02)\end{array}$ \\
\hline Error-correction term & $\begin{array}{l}-0.48^{* * *} \\
(0.01)\end{array}$ & $\begin{array}{l}-0.57^{* * *} \\
(0.01)\end{array}$ & $\begin{array}{l}-0.66^{* * *} \\
(0.01)\end{array}$ & $\begin{array}{l}-1.06^{* * *} \\
(0.01)\end{array}$ & $\begin{array}{l}-0.82^{* * * *} \\
(0.01)\end{array}$ & $\begin{array}{l}-1.11^{* * *} \\
(0.01)\end{array}$ \\
\hline \multicolumn{7}{|l|}{ Short-run } \\
\hline 1. $\triangle B E V$ & $\begin{array}{l}-0.24^{* * *} \\
(0.01)\end{array}$ & $\begin{array}{l}-0.20^{* * *} \\
(0.01)\end{array}$ & $\begin{array}{l}-0.19^{* * *} \\
(0.01)\end{array}$ & $\begin{array}{l}0.05^{* * *} \\
(0.01)\end{array}$ & $\begin{array}{l}-0.09^{* * *} \\
(0.01)\end{array}$ & $\begin{array}{l}0.08^{* * *} \\
(0.01)\end{array}$ \\
\hline $12 . \Delta B E V$ & $\begin{array}{l}-0.07^{* * *} \\
(0.01)\end{array}$ & $\begin{array}{l}-0.06^{* * *} \\
(0.01)\end{array}$ & $\begin{array}{l}-0.11^{* * *} \\
(0.01)\end{array}$ & $\begin{array}{l}0.01 \\
(0.01)\end{array}$ & $\begin{array}{l}-0.07^{* * *} \\
(0.01)\end{array}$ & $\begin{array}{l}0.03^{* * *} \\
(0.01)\end{array}$ \\
\hline$\Delta C_{c}$ & $\begin{array}{l}0.00 \\
(0.00)\end{array}$ & $\begin{array}{l}0.00 \\
(0.00)\end{array}$ & $\begin{array}{l}0.02^{* *} \\
(0.01)\end{array}$ & $\begin{array}{l}0.01 \\
(0.01)\end{array}$ & $\begin{array}{l}-0.04^{*} \\
(0.01)\end{array}$ & $\begin{array}{l}-0.01 \\
(0.01)\end{array}$ \\
\hline $12 . \Delta C_{c}$ & $\begin{array}{l}-0.00 \\
(0.00)\end{array}$ & $\begin{array}{l}-0.00 \\
(0.00)\end{array}$ & $\begin{array}{l}0.03 \\
(0.02)\end{array}$ & $\begin{array}{l}-0.00 \\
(0.01)\end{array}$ & $\begin{array}{l}-0.02 \\
(0.02)\end{array}$ & $\begin{array}{l}-0.02 \\
(0.02)\end{array}$ \\
\hline l3. $\Delta C_{c}$ & $\begin{array}{l}-0.00 \\
(0.00)\end{array}$ & $\begin{array}{l}0.00 \\
(0.00)\end{array}$ & $\begin{array}{l}0.05 \\
(0.02)\end{array}$ & $\begin{array}{l}0.02^{*} \\
(0.01)\end{array}$ & $\begin{array}{l}0.00 \\
(0.02)\end{array}$ & $\begin{array}{l}0.01 \\
(0.02)\end{array}$ \\
\hline \multicolumn{7}{|l|}{ CS-means $\left(\overline{\boldsymbol{Z}}_{t}\right)$} \\
\hline$\overline{B E V}$ & - & $\begin{array}{l}0.82^{* * *} \\
(0.01)\end{array}$ & - & $\begin{array}{l}0.97^{* * *} \\
(0.04)\end{array}$ & - & $\begin{array}{l}0.96^{* * *} \\
(0.04)\end{array}$ \\
\hline 1. $\overline{B E V}$ & - & $\begin{array}{l}-0.15^{* * *} \\
(0.01)\end{array}$ & - & $\begin{array}{l}0.01 \\
(0.02)\end{array}$ & - & $\begin{array}{l}0.04^{*} \\
(0.02)\end{array}$ \\
\hline $12 . \overline{B E V}$ & - & $\begin{array}{l}-0.10^{* * *} \\
(0.01)\end{array}$ & - & $\begin{array}{l}0.05^{*} \\
(0.02)\end{array}$ & - & $\begin{array}{l}0.06^{* *} \\
(0.02)\end{array}$ \\
\hline $13 . \overline{B E V}$ & - & $\begin{array}{l}-0.06^{* * *} \\
(0.01)\end{array}$ & - & $\begin{array}{l}0.02 \\
(0.02)\end{array}$ & - & $\begin{array}{l}0.03 \\
(0.02)\end{array}$ \\
\hline $14 . \overline{B E V}$ & - & $\begin{array}{l}-0.01 \\
(0.01)\end{array}$ & - & $\begin{array}{l}-0.00 \\
(0.02)\end{array}$ & - & $\begin{array}{l}-0.00 \\
(0.02)\end{array}$ \\
\hline$\overline{C_{c}}$ & - & $\begin{array}{l}0.08^{*} \\
(0.04)\end{array}$ & - & $\begin{array}{l}0.00 \\
(0.08)\end{array}$ & - & $\begin{array}{l}0.02 \\
(0.08)\end{array}$ \\
\hline $1 . \overline{C_{c}}$ & - & $\begin{array}{l}-0.04 \\
(0.05)\end{array}$ & - & $\begin{array}{l}0.03 \\
(0.10)\end{array}$ & - & $\begin{array}{l}0.03 \\
(0.10)\end{array}$ \\
\hline $12 . \overline{C_{c}}$ & - & $\begin{array}{l}-0.03 \\
(0.06)\end{array}$ & - & $\begin{array}{l}-0.04 \\
(0.12)\end{array}$ & - & $\begin{array}{l}-0.04 \\
(0.12)\end{array}$ \\
\hline $13 . \overline{C_{c}}$ & - & $\begin{array}{l}0.05 \\
(0.06)\end{array}$ & - & $\begin{array}{l}-0.00 \\
(0.13)\end{array}$ & - & $\begin{array}{l}0.03 \\
(0.13)\end{array}$ \\
\hline $14 . \overline{C_{c}}$ & - & $\begin{array}{l}-0.04 \\
(0.04)\end{array}$ & - & $\begin{array}{l}0.13 \\
(0.10)\end{array}$ & - & $\begin{array}{l}0.11 \\
(0.11)\end{array}$ \\
\hline Constant & $\begin{array}{l}1.18^{* * *} \\
(0.06)\end{array}$ & $\begin{array}{l}0.06 \\
(0.06)\end{array}$ & $\begin{array}{l}1.34^{* * *} \\
(0.10)\end{array}$ & $\begin{array}{l}-0.14 \\
(0.11)\end{array}$ & $\begin{array}{l}-0.38 \\
(0.97)\end{array}$ & $\begin{array}{l}-0.33 \\
(0.23)\end{array}$ \\
\hline Hausman test $p$-value & & 0.32 & & 0.29 & & - \\
\hline
\end{tabular}

Note: Standard errors in parentheses. Groups: 594, Obs.: 40,392. *** $p<0.001,{ }^{* *} p<0.01,{ }^{*} p<0.05$ 
Table A4

Results I - PHEV registrations and overall charging capacity (= capacity effect)

\begin{tabular}{|c|c|c|c|c|c|c|}
\hline \multirow[t]{2}{*}{$\begin{array}{l}\text { Dep. var.: } \\
\triangle P H E V\end{array}$} & \multicolumn{2}{|c|}{$\begin{array}{l}\text { Dynamic fixed effects } \\
\text { (DFE) }\end{array}$} & \multicolumn{2}{|c|}{$\begin{array}{l}\text { Pooled mean group } \\
\text { (PMG) }\end{array}$} & \multicolumn{2}{|c|}{$\begin{array}{l}\text { Mean group } \\
(\mathrm{MG})\end{array}$} \\
\hline & (1) & $(2)$ & $(3)$ & $(4)$ & $(5)$ & $(6)$ \\
\hline $\begin{array}{l}\text { Long-run coefficient } \\
\sum_{(=\text {capacity })} \text { charg. capacity }\left(C_{c}\right)\end{array}$ & $\begin{array}{l}0.02^{* * *} \\
(0.00)\end{array}$ & $\begin{array}{l}0.00^{*} \\
(0.00)\end{array}$ & $\begin{array}{l}0.02^{* * *} \\
(0.00)\end{array}$ & $\begin{array}{l}0.00^{* *} \\
(0.00)\end{array}$ & $\begin{array}{l}0.04 \\
(0.05)\end{array}$ & $\begin{array}{l}0.02 \\
(0.01)\end{array}$ \\
\hline Error-correction term & $\begin{array}{l}-0.44^{* * *} \\
(0.01)\end{array}$ & $\begin{array}{l}-0.62^{* * *} \\
(0.01)\end{array}$ & $\begin{array}{l}-0.49^{* * *} \\
(0.01)\end{array}$ & $\begin{array}{l}-1.04^{* * *} \\
(0.02)\end{array}$ & $\begin{array}{l}-0.69 * * * \\
(0.02)\end{array}$ & $\begin{array}{l}-1.12^{* * *} \\
(0.02)\end{array}$ \\
\hline \multicolumn{7}{|l|}{ Short-run coefficients } \\
\hline 1. $\triangle P H E V$ & $\begin{array}{l}-0.27^{* * *} \\
(0.01)\end{array}$ & $\begin{array}{l}-0.16^{* * *} \\
(0.01)\end{array}$ & $\begin{array}{l}-0.28^{* * *} \\
(0.01)\end{array}$ & $\begin{array}{l}0.06^{* * *} \\
(0.01)\end{array}$ & $\begin{array}{l}-0.16^{* * *} \\
(0.01)\end{array}$ & $\begin{array}{l}0.10^{* * *} \\
(0.01)\end{array}$ \\
\hline $12 . \triangle P H E V$ & $\begin{array}{l}-0.15^{* * *} \\
(0.01)\end{array}$ & $\begin{array}{l}-0.09^{* * *} \\
(0.01)\end{array}$ & $\begin{array}{l}-0.17^{* * *} \\
(0.01)\end{array}$ & $\begin{array}{l}0.00 \\
(0.01)\end{array}$ & $\begin{array}{l}-0.11^{* * *} \\
(0.01)\end{array}$ & $\begin{array}{l}0.03^{* *} \\
(0.01)\end{array}$ \\
\hline$\Delta C_{c}$ & $\begin{array}{l}0.00 \\
(0.00)\end{array}$ & $\begin{array}{l}0.00 \\
(0.00)\end{array}$ & $\begin{array}{l}0.01^{* *} \\
(0.00)\end{array}$ & $\begin{array}{l}-0.00 \\
(0.01)\end{array}$ & $\begin{array}{l}-0.04^{* *} \\
(0.01)\end{array}$ & $\begin{array}{l}-0.01 \\
(0.01)\end{array}$ \\
\hline $1 . \Delta C_{c}$ & $\begin{array}{l}-0.00 \\
(0.00)\end{array}$ & $\begin{array}{l}-0.00 \\
(0.00)\end{array}$ & $\begin{array}{l}0.01^{*} \\
(0.00)\end{array}$ & $\begin{array}{l}-0.00 \\
(0.01)\end{array}$ & $\begin{array}{l}-0.03^{* *} \\
(0.01)\end{array}$ & $\begin{array}{l}-0.01 \\
(0.01)\end{array}$ \\
\hline $12 . \Delta C_{c}$ & $\begin{array}{l}-0.00 \\
(0.00) \\
\end{array}$ & $\begin{array}{l}0.00 \\
(0.00)\end{array}$ & $\begin{array}{l}0.01^{*} \\
(0.00) \\
\end{array}$ & $\begin{array}{l}0.01 \\
(0.01)\end{array}$ & $\begin{array}{l}-0.03^{* *} \\
(0.01) \\
\end{array}$ & $\begin{array}{l}0.01 \\
(0.01)\end{array}$ \\
\hline \multicolumn{7}{|l|}{$C S$-means $\left(\overline{\boldsymbol{Z}}_{t}\right)$} \\
\hline$\overline{P H E V}$ & - & $\begin{array}{l}0.80^{* * *} \\
(0.01)\end{array}$ & - & $\begin{array}{l}0.91^{* * *} \\
(0.04)\end{array}$ & - & $\begin{array}{l}0.91^{* * *} \\
(0.04)\end{array}$ \\
\hline 1. $\overline{P H E V}$ & - & $\begin{array}{l}-0.16^{* * *} \\
(0.01)\end{array}$ & - & $\begin{array}{l}0.00 \\
(0.02)\end{array}$ & - & $\begin{array}{l}0.03 \\
(0.02)\end{array}$ \\
\hline 12. $\overline{P H E V}$ & - & $\begin{array}{l}-0.04^{* * *} \\
(0.01)\end{array}$ & - & $\begin{array}{l}0.04 \\
(0.02)\end{array}$ & - & $\begin{array}{l}0.06^{* *} \\
(0.02)\end{array}$ \\
\hline 13. $\overline{P H E V}$ & - & $\begin{array}{l}-0.08^{* * *} \\
(0.01)\end{array}$ & - & $\begin{array}{l}0.02 \\
(0.02)\end{array}$ & - & $\begin{array}{l}0.03 \\
(0.02)\end{array}$ \\
\hline $14 . \overline{P H E V}$ & - & $\begin{array}{l}-0.01 \\
(0.01)\end{array}$ & - & $\begin{array}{l}-0.01 \\
(0.02)\end{array}$ & - & $\begin{array}{l}-0.02 \\
(0.02)\end{array}$ \\
\hline$\overline{C_{c}}$ & - & $\begin{array}{l}0.04 \\
(0.02)\end{array}$ & - & $\begin{array}{l}-0.09 \\
(0.09)\end{array}$ & - & $\begin{array}{l}-0.06 \\
(0.10)\end{array}$ \\
\hline 1. $\overline{C_{c}}$ & - & $\begin{array}{l}0.00 \\
(0.04)\end{array}$ & - & $\begin{array}{l}0.08 \\
(0.12)\end{array}$ & - & $\begin{array}{l}0.09 \\
(0.11)\end{array}$ \\
\hline $12 . \overline{C_{c}}$ & - & $\begin{array}{l}-0.02 \\
(0.04)\end{array}$ & - & $\begin{array}{l}0.11 \\
(0.16)\end{array}$ & - & $\begin{array}{l}0.05 \\
(0.16)\end{array}$ \\
\hline $13 . \overline{C_{c}}$ & - & $\begin{array}{l}0.02 \\
(0.04)\end{array}$ & - & $\begin{array}{l}-0.02 \\
(0.15)\end{array}$ & - & $\begin{array}{l}-0.04 \\
(0.14)\end{array}$ \\
\hline $14 . \overline{C_{c}}$ & - & $\begin{array}{l}-0.01 \\
(0.03) \\
\end{array}$ & - & $\begin{array}{l}0.02 \\
(0.09) \\
\end{array}$ & - & $\begin{array}{l}-0.01 \\
(0.10) \\
\end{array}$ \\
\hline Constant & $\begin{array}{l}0.76^{* * *} \\
(0.04)\end{array}$ & $\begin{array}{l}0.01 \\
(0.04)\end{array}$ & $\begin{array}{l}0.58^{* * *} \\
(0.06)\end{array}$ & $\begin{array}{l}-0.16 \\
(0.11)\end{array}$ & $\begin{array}{l}-0.24 \\
(0.16)\end{array}$ & $\begin{array}{l}-0.71 \\
(0.58)\end{array}$ \\
\hline Hausman test ( $p$-value) & & 0.14 & & 0.15 & & - \\
\hline
\end{tabular}

Note: Standard errors in parentheses. Groups: 594, Obs.: 40,392. ${ }^{* * *} p<0.001,{ }^{* *} p<0.01,{ }^{*} p<0.05$ 